\title{
Source rock and shale oil potential of the Pabdeh Formation (Middle-Late Eocene) in the Dezful Embayment, southwest Iran
}

\author{
$\begin{array}{llll}\text { B. Alizadeh } & \text { A. Opera } & \text { M. Kalani } & \\ & \text { M. Alipour } & \end{array}$ \\ 'Department of Petroleum Geology and Sedimentary Basins, Faculty of Earth Sciences, Shahid Chamran University of Ahvaz \\ Ahvaz, Golestan Boulevard, Pin: 613578-3151 Iran. E-mail: alizadeh@scu.ac.ir
}

2Petroleum Geology and Geochemistry Research Center (PGGRC), Shahid Chamran University of Ahvaz

Ahvaz, Golestan Boulevard, Pin: 613578-3151, Iran

${ }^{3}$ Department of Geology, National Iranian South Oil Company (NISOC)

Ahvaz, Pasdaran Highway, Pin: 61735-1333, Iran

\begin{abstract}
The Pabdeh Brown Shale Unit (BSU) is an organic-rich calcareous mudstone within the Paleogene Pabdeh Formation, which has not yet been investigated in detail. A total of 166 core and cutting samples were selected from four wells in the Dezful Embayment to investigate the organic geochemical and mineralogical compositions, as well as the shale oil potential of the BSU. X-Ray Diffraction (XRD) results show that it is mainly comprised of calcite (53wt.\%), clay minerals (25wt.\%) and quartz (14wt.\%). Total Organic Content (TOC) values generally range from 1 to $9 \mathrm{wt} . \%$ (avg. 4.2, 2.9, 5.2 and 3.3wt.\%, for GS, KR, RR and RS wells, respectively) with Hydrogen Index (HI) values ranging between 400 and $650 \mathrm{mg} \mathrm{HC} / \mathrm{g}$ TOC. Based on average values of $\mathrm{T}_{\max }$ and vitrinite reflectance, as well as saturate biomarker ratios, the BSU is immature at wells RR and RS (ranging from 0.3 to $0.53 \%$ ) and its maturity increases northward at wells KR and GS (ranging from $0.5 \%$ to $0.67 \%$ ). The organic matter is dominated by Type II kerogen and is generally composed of liptinite and amorphous material with minor terrestrial input. Based on various biomarker parameters, the organic matter was most likely deposited under anoxic marine conditions. The favorable mineralogical composition (i.e. presence of brittle minerals) and organic geochemical properties (i.e. TOC $>2 \mathrm{wt} \%$ and Type II kerogen) support the conclusion that the Pabdeh BSU displays a considerable shale oil potential where it attains appropriate thermal maturity.
\end{abstract}

Pabdeh BSU. Organic matter. Biomarkers. Mineral composition. Oil potential.

\section{INTRODUCTION}

The most critical element for the existence of a petroleum system is the presence of a source rock capable of generating adequate amounts of hydrocarbons (Magoon and Dow, 1994). Although the source rocks were traditionally regarded to account for the conventional resources, organic-rich source rocks can contain huge amounts of unconventional hydrocarbon resources (Curiale and Curtis, 2016). Therefore, recent trends in source rock evaluation projects mostly recommend a thorough investigation about the unconventional shale gas and shale

(C) B. Alizadeh, A. Opera, M. Kalani, M. Alipour, 2020 CC BY-SA 
oil potentials associated with a petroleum system (Gross et al., 2015; Jarvie, 2012, 2014; Li et al., 2018; Permanyer et al., 2016; Song et al., 2017; Uffmann et al., 2012; Zhao et al., 2014).

The Middle Cretaceous-Early Miocene Petroleum System (Fig. 1), is one of the five petroleum systems recognized in the Zagros Fold Belt and the adjacent Persian Gulf Basin (Bordenave and Hegre, 2010; Bordenave, 2014). This petroleum system comprises two active source rocks (i.e. the Kazhdumi and Pabdeh formations) with two reservoirs (i.e. the Asmari Formation and the Bangestan Group). The Pabdeh Formation is recognized as the only active hydrocarbon generating Paleogene source rock (Fig. 1 ), and is a secondary source for the Middle CretaceousEarly Miocene petroleum system in the Dezful Embayment (Alizadeh et al., 2012; Bordenave and Hegre, 2010; Opera et al., 2013). In contrast, the Albian Kazhdumi Formation has had substantial contribution to the Asmari reservoir by vertical migration through faults and fracture networks during the Zagros orogeny. Nevertheless, contributions from both source intervals continue until the present (Bordenave and Burwood, 1990; Bordenave and Hegre, 2010).

Several studies have investigated the petroleum systems and organic geochemistry of oils and source rocks in the Zagros Fold Belt (Ala et al., 1980; Asadi Mehmandosti et al., 2015; Baniasad et al., 2016; Bordenave and Hegre, 2010; Mashhadi et al., 2015; Opera et al., 2013; Rabbani et al., 2014; Soleimani and Zamani, 2015). In addition, many studies have characterized the Kazhdumi source rock and associated hydrocarbons in the Dezful Embayment (e.g. Alizadeh et al., 2017, 2018a; Baniasad et al., 2019; Sfidari et al., 2016). However, the hydrocarbon potential of the Pabdeh Formation is not fully addressed in the Dezful Embayment and, except for some preliminary and local geochemical studies, little information exists about its organic geochemistry and generation potential (e.g. Alizadeh et al., 2018b, 2019; Bordenave, 2014; Hatampour, 2014; Karimi et al., 2016a, b). Based on previous studies, the Pabdeh Formation has TOC (2-5wt.\%) and HI values (300$600 \mathrm{mg} \mathrm{HC} / \mathrm{g}$ TOC) typical of Type II organic matter with low thermal maturity $\left(\mathrm{R}_{\mathrm{O}} \leq 0.6 \%\right)$. Existing oil-source rock correlation studies have shown that the Pabdeh Formation becomes an important source rock for the Asmari reservoirs in the NE parts of the Dezful Embayment (i.e. where the Kazhdumi Formation constitutes a non-source limestone facies). By contrast, in the central and SW parts of the Dezful Embayment, the main source rock is the Kazhdumi Formation, while the Pabdeh Formation does not reach sufficient maturity for hydrocarbon generation (immature to early mature) (Bordenave and Hegre, 2010).

The Brown Shale Unit (BSU) constitutes the middle part of the Pabdeh Formation throughout the Dezful
Embayment. However, the exact geographic distribution of this unit and its extension into the adjacent basins (Lurestan and Fars) are still unclear. Recent drillings in the Dezful Embayment have indicated that the BSU, aside from being a significant source rock for the Asmari reservoir can have considerable potential for shale oil resource development, thereby opening a new exploration doorway. The objectives of this study are to comprehensively investigate the mineralogical and organic geochemical characteristics of the BSU in order to shed more light on the possible shale oil potential in the Dezful Embayment. We build upon fresh analytical data obtained from drill cores and cutting samples from four major oilfields located to the south of the Dezful Embayment (Fig. 2). Our results provide valuable insights into the dynamic evolution of the Middle CretaceousEarly Miocene petroleum system in the southern Dezful Embayment and have significant implications for future exploration and production activities.

\section{GEOLOGICAL SETTING}

The Zagros Fold Belt is part of the Alpine-Himalayan orogenic system that resulted from the closure of the Neo-Tethys ocean between the Arabian and European plates during Cenozoic times (Alavi and Mahdavi, 1994; Homke et al., 2004). The Zagros Fold Belt, characterized by NW-SE trending folds and thrust faults, extends over $2000 \mathrm{~km}$ from eastern Turkey and Kurdistan region in north Iraq to southern Iran (Bahroudi and Talbot, 2003; Sherkati et al., 2006). According to the structural and the stratigraphic features several main domains are defined from NW to SE including the Lurestan area, the Dezful Embayment, the Izeh Zone and the Fars Province (Sepehr and Cosgrove, 2004) (Fig. 2). The Dezful Embayment, which contains the most important oil reservoirs in the Zagros Fold Belt is bounded on the northwest by the transverse strike-slip Balarud Fault Zone, on the northeast by the Izeh Fault Zone, on the north by the Mountain Front Fault, and on the east by the Kazerun Fault Zone (Mouthereau et al., 2012; Sepehr and Cosgrove, 2004) (Fig. 2).

From the stratigraphic point of view, a thick sedimentary package exists in the Dezful Embayment, which comprises 9-12km-thick sediments formed under various tectonic settings, i.e. passive margin during Paleozoic and Mesozoic and active compressional setting during Cenozoic. Chronostratigraphic correlations of rock units indicate continuous sedimentation with no main uplift/erosion events from Jurassic to Early Miocene (Fig. 1). A brief episode of instability existed at the end of Cenomanian; this influenced the depositional environments, the source rocks formation and the reservoirs in the Dezful Embayment (Bordenave and Hegre, 2005). 


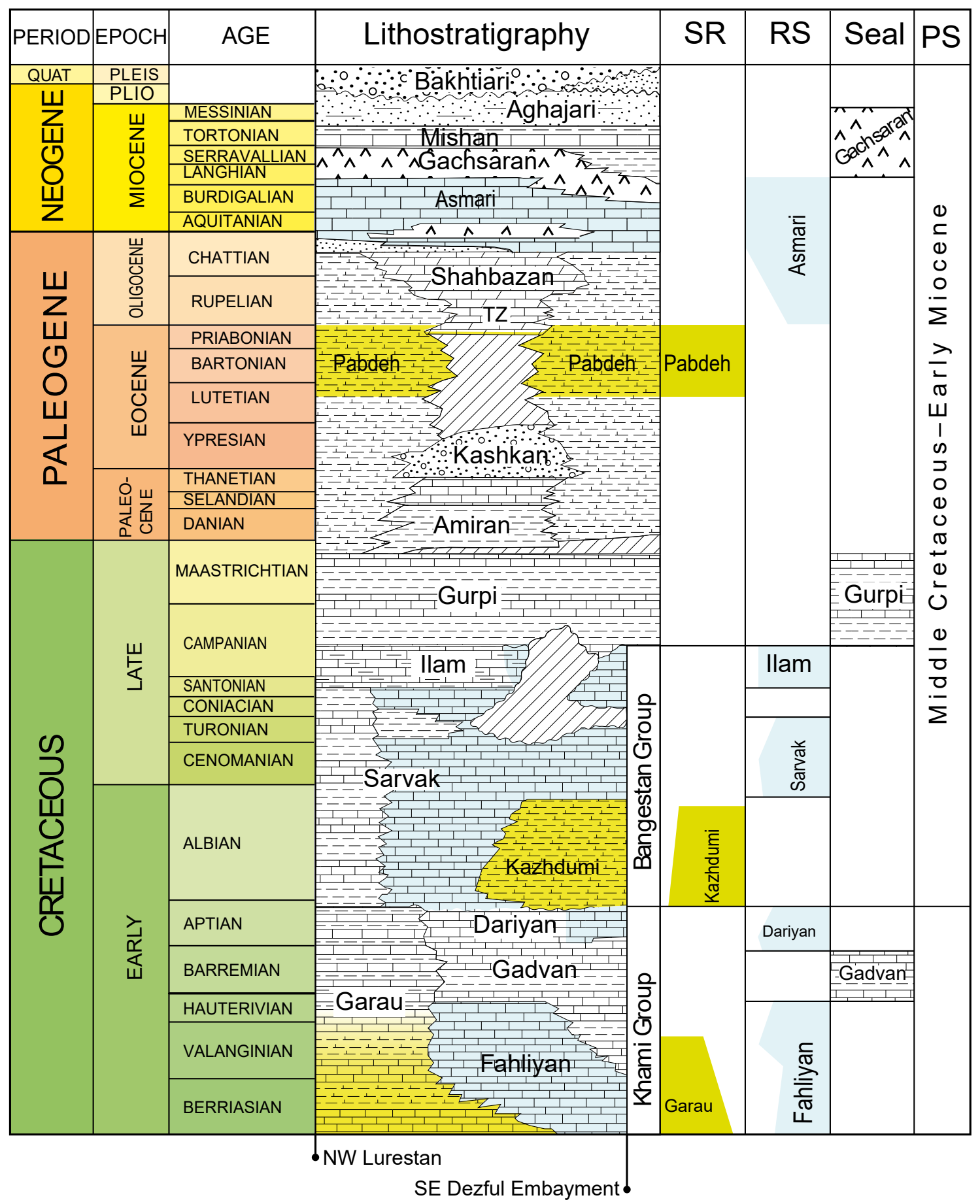

FIGURE 1. General lithostratigraphic chart of the Zagros Fold Belt including Dezful Embayment and Lurestan areas (modified from Bordenave and Hegre, 2010). Note: $S R=$ source rock; $R S=$ reservoir rock; $P S=$ petroleum system; TZ= Tale-Zang.

The Paleocene-Eocene transgression resulted in the deposition of neritic to basinal marls and argillaceous limestone of the Pabdeh Formation in a narrow foredeep basin (Bordenave and Hegre, 2010). This Formation encompasses the entire Zagros Fold Belt, extends widely from Lurestan to Fars, which contains planktonic fauna throughout the basin (Habibi et al., 2017; James and Wynd, 1965). At the base, the Pabdeh Formation overlies disconformably the Gurpi Formation, whereas its upper boundary is transitional with the Asmari Formation (Fig. 1). Throughout the Dezful Embayment, the Pabdeh Formation is divided into three informal units. The lower 


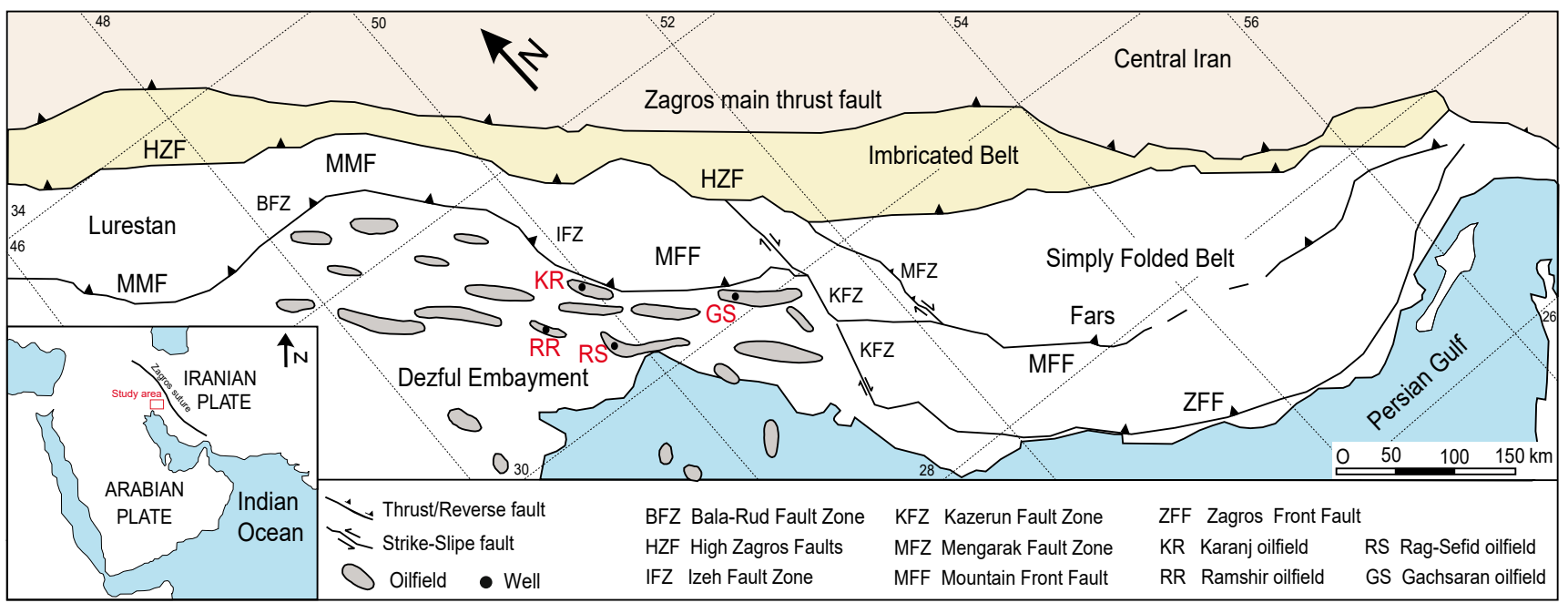

FIGURE 2. Location map of the main structural subdivisions of the Zagros Fold Belt including the study area (modified from Sepehr and Cosgrove, 2004).

and upper units were deposited under oxic conditions and have low organic contents. However, the middle unit formed under anoxic conditions and has a relatively higher organic content (Bordenave, 2014).

From Oligocene/Miocene times onward, the collision between the Arabian and Iranian plates developed with a progressive SW migration of deformation and topographic build-up (i.e. Sanandaj Sirjan Zone, 20-15Ma; High Zagros, 12-8Ma; Simply Folded Belt including Dezful Embayment, 5-0Ma) (Agard et al., 2011).

\section{MATERIAL AND METHODS}

Conventional well logs including Spectral and Computed Gamma-Ray (SGR and CGR), sonic, neutron and density porosities, and resistivity were used for interval recognitions and petrophysical investigation of the Pabdeh BSU in the studied wells. In this study, about $324 \mathrm{~m}$ of core samples (GS: 114m; KR: 30m; RR: 92m and RS: $88 \mathrm{~m}$ ) were studied macroscopically prior to sample selection. Eventually, a total of 143 core and 23 cutting samples of the BSU were obtained from 4 wells drilled in the southern Dezful Embayment (Fig. 2).

A subset of 34 core and cutting samples were selected for X-Ray Diffraction (XRD) analysis on both bulk sample and clay fractions. X-ray clay fraction analysis were carried out using Mg-saturated air-dried samples which were subsequently treated with ethylene glycol and heated to $550^{\circ} \mathrm{C}$ as suggested by Poppe et al. (2001). The XRD patterns of the samples were acquired using a PANalytical XPert Pro Multi-Purpose XRD System with
$\mathrm{CuK} \alpha$ radiation, and PIXcel0D detector, which provides high signal to noise ratio and allows high data collection speeds. The datasets were collected from 2 to $65^{\circ} 2 \theta$ for bulk samples, and $2-35^{\circ} 2 \theta$ for clay samples. The BGMN software (Bergmann et al., 1998) was used to quantify the mineralogical phases in the bulk samples. With the BGMN approach, quantification is based on a Rietveld refinements of simulated patterns of mineral phases. Structure files were available directly from the BGMN setup package and/or the BGMN website (Bergmann et al., 2014) or works by the BGMN Group. The Scanning Electron Microscopy (SEM) observation was performed on these samples as a complementary analysis for the mineralogical characterization. The secondary electron and backscattered electron images were obtained using a Hitachi XL30 Scanning Electron Microscope equipped with an Energy Dispersive X-ray (EDAX) spectrometer to identify the minerals in the samples.

In order to assess the quantity, quality and maturity of the organic matter contained within the Pabdeh BSU, a total of 166 core and cutting samples were analyzed applying the Rock-Eval 6 pyrolysis technique. Following the standard procedure described by Behar et al. (2001), aliquots of pulverized samples $(70-80 \mathrm{mg})$ were loaded into crucibles and various parameters (e.g. $\mathrm{S}_{1}, \mathrm{~S}_{2}, \mathrm{~S}_{3}$ and $\mathrm{T}_{\max }$ ) were measured. Additional parameters including the total organic carbon (TOC), hydrogen index (HI), oxygen index (OI) and Production Index (PI) were calculated from these measurements.

For petrographic analyses and vitrinite reflectance measurement, a subset of 32 polished mounts were provided from core and cutting chips embedded in epoxy 
resin. Polished samples were prepared according to standard procedures described by Taylor et al. (1998). Optical microscopy was performed using a Zeiss Axioplan II polarizing microscope, equipped with J\&M photomultiplier. Maceral analysis was conducted under incident white light and blue-light excitation (fluorescence mode). Standards (\%Ro: $0.43,0.56$ and 0.95 ) were used to calibrate the photometer. Reflectance was measured on randomly oriented vitrinite macerals under oil immersion with 100× magnification objective at a wavelength of $546 \mathrm{~nm}$.

Nineteen core samples were selected for biomarker analysis from the studied shale unit. The indigenous bitumen was extracted from the samples using a Soxhlet apparatus with a mixture of dichloromethane (DCM) and methanol $\left(\mathrm{CH}_{3} \mathrm{OH}\right)(90: 10 \mathrm{v}: \mathrm{v})$. After asphaltene precipitation (by adding excess amounts of n-heptane), extracts were fractionated into saturate, aromatic and polar compounds by liquid column chromatography. The saturate hydrocarbon fractions were analyzed using a gas chromatograph equipped with a $50 \mathrm{~m}$ DB-1 fused silica capillary column (internal diameter of $0.25 \mathrm{~mm}$ and film thickness of $0.25 \mu \mathrm{m}$ ) and was coupled to a Finnigan MAT GCQ ion trap mass spectrometer. The gas chromatograph was programmed to operate with an oven temperature of $70^{\circ} \mathrm{C}$, ramped to $300^{\circ} \mathrm{C}$ at $4^{\circ} \mathrm{C} /$ min, and held under isothermal conditions for 15 minutes. The sample was injected in splitless mode with the injector temperature at $275^{\circ} \mathrm{C}$. Helium was used as a carrier gas and a mass range between $\mathrm{m} / \mathrm{z} 50$ to 650 was scanned by the spectrometer. The relative abundance of individual compounds was calculated by measuring peak areas in relation to the internal standard (deuterated n-tetracosane); then various components were recognized following published works (Peters et al., 2005; Waples and Machihara, 1992).

\section{RESULTS}

\section{Petrophysics}

The BSU is distinguishable throughout the entire Dezful Embayment with respect to its distinctive petrophysical characteristics. This unit is distinguished from the upper and lower parts of the Pabdeh Formation by the relatively higher CGR and SGR response (up to 35 API and 10 to 150 API, respectively) lower sonic velocities (from approximately 3500 to $5500 \mathrm{~m} / \mathrm{s}$, avg. $4000 \mathrm{~m} / \mathrm{s}$ ), higher resistivity (approximately up to 50ohm.m for RR and RS wells and more than 200ohm.m for GS and KR wells), and higher neutron and density porosities (Fig. 3A-D). A typical CGR and SGR response for the BSU begins with lower readings at the base, progressively increases to higher readings in the middle (with high frequency variations), and eventually decreases to lower readings at the top (Fig. 3A-D). Simultaneously, an increase in the CGR and SGR response and the separation between them can indicate linear relationship between concentrations of organic matter and uranium enrichment for the BSU (Fig. 3A-D). As shown in the Organic Petrography chapter, common presence of hydrogen-rich organic matter can be linked with a higher productivity and/or preservation of organic matter due to change from oxic to anoxic conditions (i.e. during sea level rise) (Fang et al., 1993).

\section{Lithology, lithofacies and mineralogy}

Lithologically, the BSU mainly contains bituminous marls interbedded with argillaceous limestone in the Dezful Embayment. Generally, these marls and limestones have reflective brownish appearance in drilling core and cuttings, which is probably due to the high abundance of organic matter (Fig. 4). In addition, macroscopic observations reveal that the samples mostly comprise dark grey to brown organic-rich argillaceous limestones alternating with light colored thin carbonatic interbeds (Fig. 4). Relatively higher thermal maturities in KR and GS samples have given rise to prominent a few centimeters-scale oil-stains and solid bitumen (Fig. 4C).

Thin-section and SEM studies show that the Pabdeh BSU consists mainly of fine to medium laminated wackestone and wackestone-packstone lithofacies (Fig. $5 \mathrm{~A}, \mathrm{~B}, \mathrm{C})$. Skeletal planktonic foraminifera, phosphatic and glauconitized fragments, quartz and pyrite are the main constituents visible under the optical microscope. Organic matter is also abundant (Fig. 5D). Quartz commonly fills the skeletal fragments (Fig. 5E, F). Pyrite framboids become abundant in mud-rich layers (Fig. 5G, H).

X-ray Quantitative Phase Analyses (QPA) reveals that the BSU is mainly composed of calcite, clay minerals, and quartz, with minor amount of ankerite, dolomite and pyrite (Table 1; Fig. 3A-D). Calcite is the dominant mineral ranging from 31 to $71 \mathrm{wt} . \%$, with an average of 53 wt. $\%$. Clay minerals are the second most common mineral constituent including kaolinite (up to $31 \mathrm{wt} . \%$, avg. $11 \mathrm{wt} . \%$ ), illite/smectite mixed layer (5 to $24 \mathrm{wt} . \%$, avg. $14 \mathrm{wt} . \%$ ) and some chlorite (up to $5.75 \mathrm{wt} . \%$ ). Smectite is lacking most likely due to increased burial depths since unstable smectite transforms into illite in the form of mixed layer illite/smectite at temperatures higher than $60-80^{\circ} \mathrm{C}$ (Bjørlykke, 2010; Nadeau, 2011). The proportion of quartz ranges from 3 to $35 \mathrm{wt} . \%$ (avg. 14wt.\%). The pyrite content ranges up to $2 \mathrm{wt}$.\%. Feldspars (K-feldspar and plagioclase) are lacking except for two samples from wells RS and RR (2.4 and $0.8 \mathrm{wt} . \%$, respectively). 

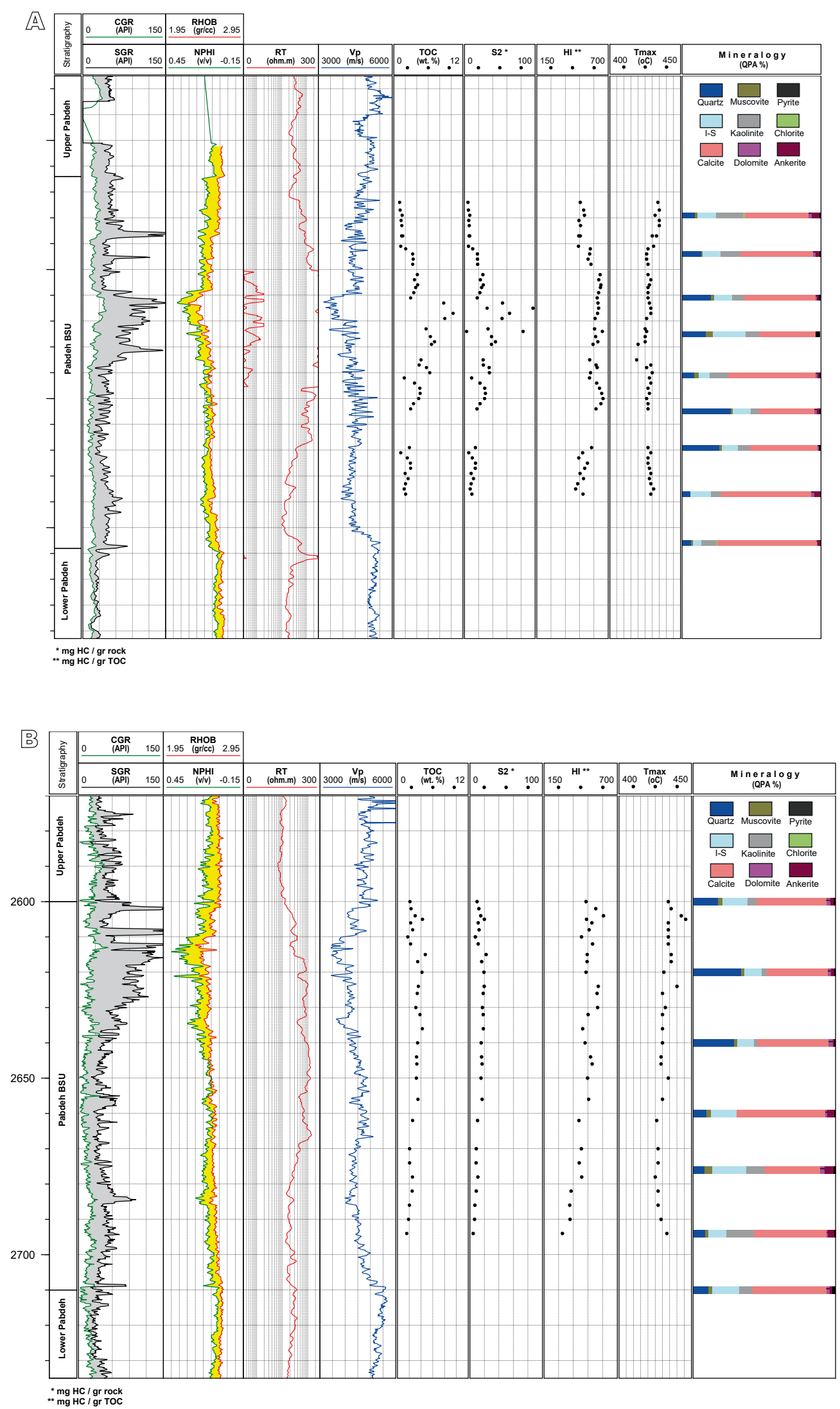

FIGURE 3. Vertical plots of petrophysical log curves including computed gamma-ray (CGR), spectral gamma-ray (SGR), density (RHOB), neutron (NPHI), resistivity (RT) and sonic (Vp) along with the bulk geochemical data (TOC, S2, HI and Tmax), and mineral composition of four studied wells in A) GS, B) KR, C) RR and D) RS. 

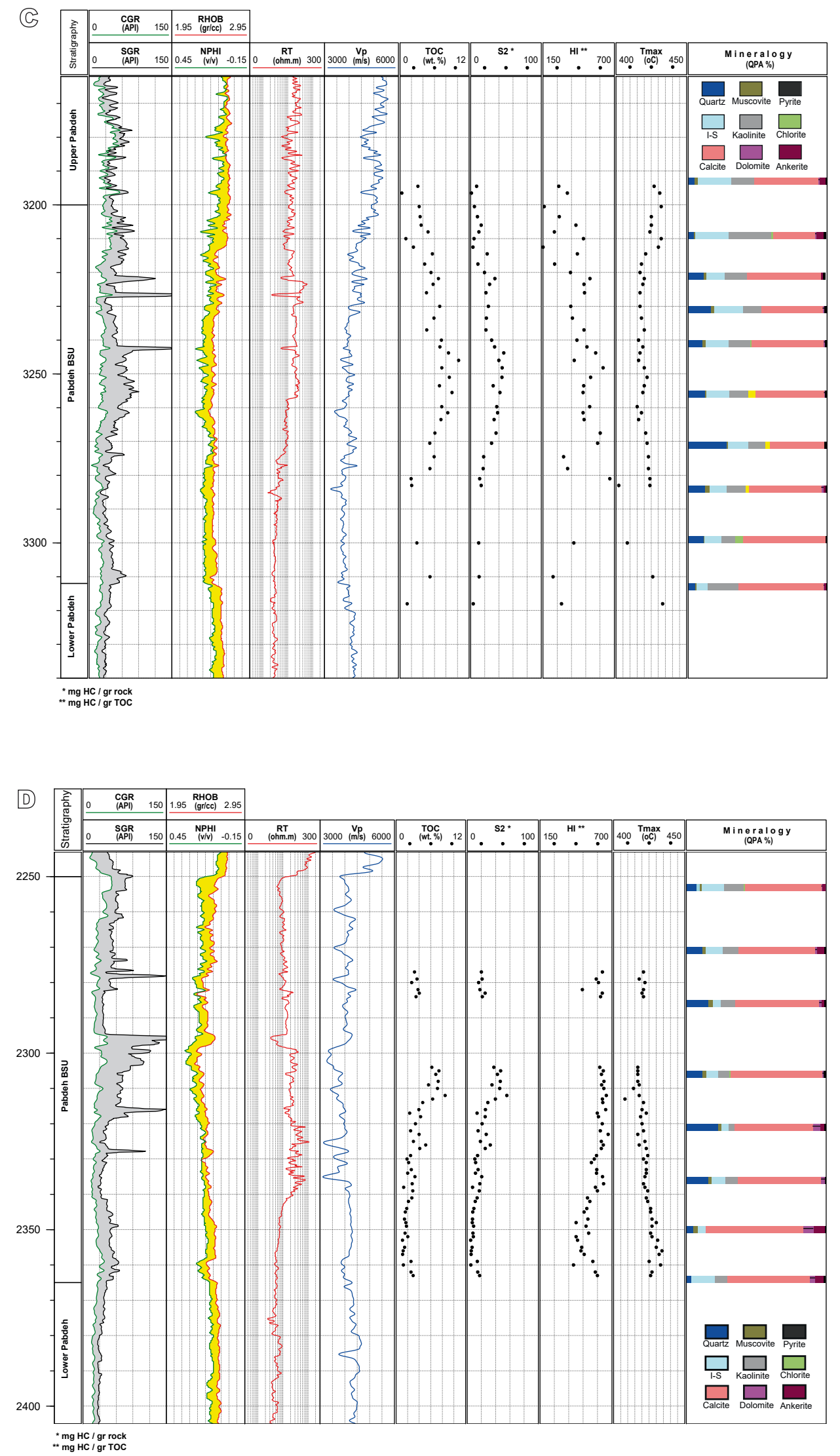

FIGURE 3. Continued. 


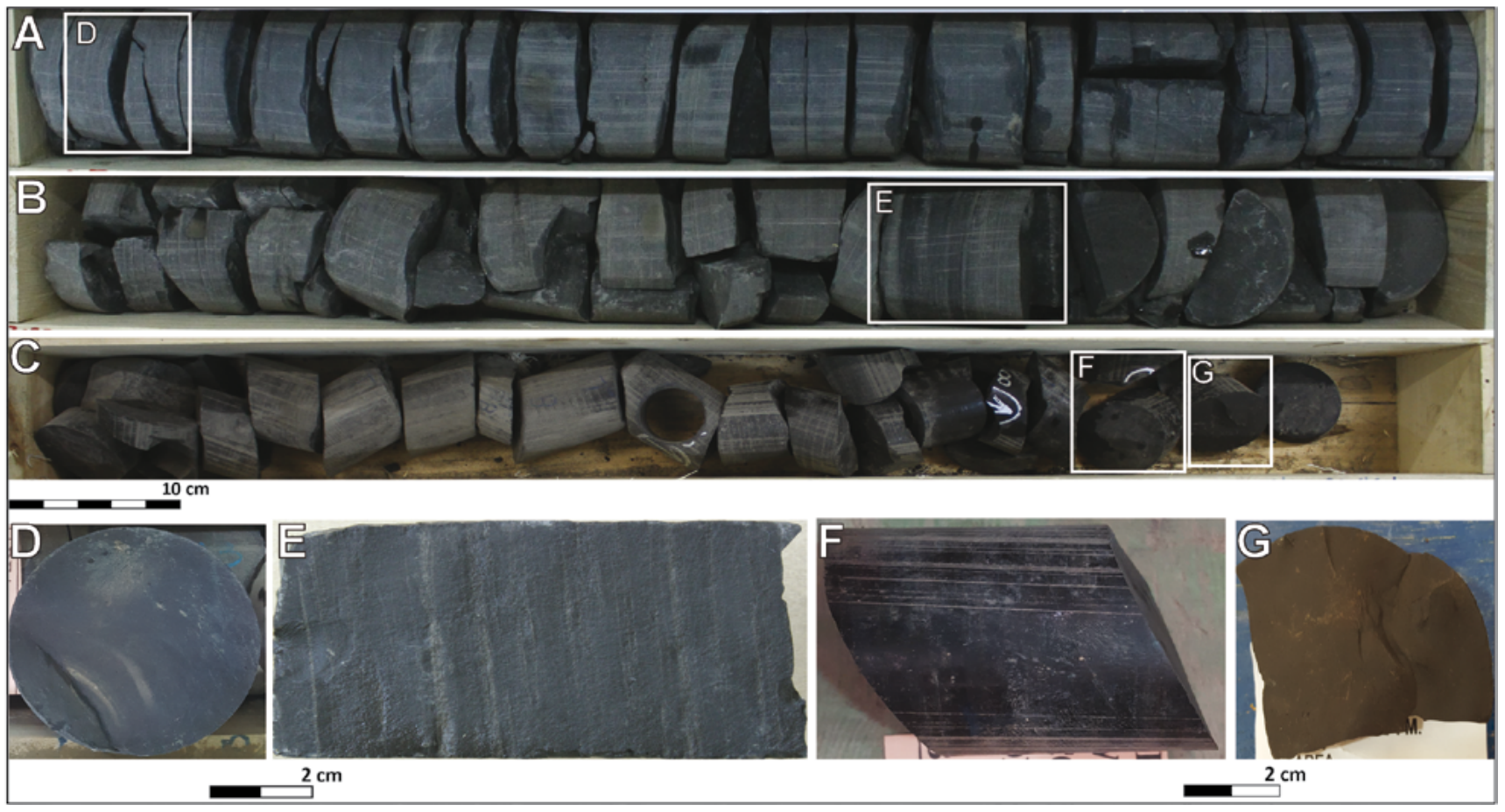

FIGURE 4. Selected core photographs of the Pabdeh BSU (A: KR-2600m; B: KR-2608m and C: GS-2512m): A and D) gray to dark gray fine laminated to massive argillaceous limestone; B and E) gray to dark gray fine laminated argillaceous limestone; C, F and G) dark brown organic-rich massive calcareous mudstone, oil and solid bitumen visible on the wall of the core sample.

\section{Rock-Eval pyrolysis}

Rock-Eval pyrolysis data is listed in Table I and plotted against depth for all studied wells in Figure 3. The TOC values for the BSU show a wide range of variation in the sampled wells, with relatively higher average values in GS and RR compared to KR and RS wells (avg. 4.17, 2.9, 5.2 and 3.3wt.\%, for GS, KR, RR and RS wells, respectively). Rock-Eval $S_{1}$ and $S_{2}$ yields of the BSU range from $0.1-6.5$ and 3-101mg $\mathrm{HC} / \mathrm{g}$ rock, respectively (Table I). The $\mathrm{HI}$ values vary generally between 400 and $650 \mathrm{mg} \mathrm{HC/g}$ TOC. The middle part of the BSU displays higher TOC and HI values, which is in compliance with the increase in the gamma-ray readings and the abundance of clay mineral (Fig. 3A-D). The $\mathrm{T}_{\max }$ values of studied samples from KR and GS wells are relatively higher $\left(\geq 430^{\circ} \mathrm{C}\right)$ compared to wells RR and $\mathrm{RS}\left(<425^{\circ} \mathrm{C}\right)$.

\section{Organic petrography}

Microscopic examinations indicate that the BSU contains mainly liptinite (alginite) and Amorphous Organic Matter $(\mathrm{AOM})$ with limited input of terrestrial vitrinite and inertinite macerals in agreement with previous studies (e.g. Opera et al., 2013). Liptinite macerals are morphologically similar to telalginite and lamalginite, which are present in most of the studied shale samples. These alginite materials show bright yellow to yellowish fluorescent under blue-light excitation (Fig. $6 \mathrm{~A}-\mathrm{C})$. The vitrinite and inertinite macerals are small in size and have low abundances in the studied samples (Fig. 6D-F). Some samples at well RR indicate relatively higher concentration of vitrinite particles. This data is also in agreement with the relatively lower $\mathrm{HI}$ values calculated for the samples from this well (Table I) and probably indicates relatively higher contribution of terrigenous organic matter in the mentioned location (Hunt, 1996). Petrographic observations by incident white light indicate that some samples have bitumen staining and solid bitumen, particularly in KR well (Fig. 6G-H). The representation of bitumen staining and solid bitumen indicates kerogen conversion from these shale samples upon reaching maturity corresponding to oil generation window. High content of algal-derived macerals and amorphous organic matter in the organic-rich shales suggest that the BSU contain Type II organic matter deposited under open marine settings. This is consistent with results obtained from Rock-Eval pyrolysis data (Table I). Petrographic inspections indicate that framboidal pyrite crystals are abundant in different sizes in all studied samples (Fig. 5). This observation is also supported by SEM microscope (Fig. 5G, H). The presence of framboidal pyrite could indicate a reducing depositional conditions for the studied wells (Zhao et al., 2014).

Vitrinite reflectance measurements were used to assess the maturity level of the BSU. The results of mean random Vitrinite Reflectance measurements (VRr) for the studied wells are given in Table I. Most of the measurements show a low standard deviation and a unimodal pattern, indicating 

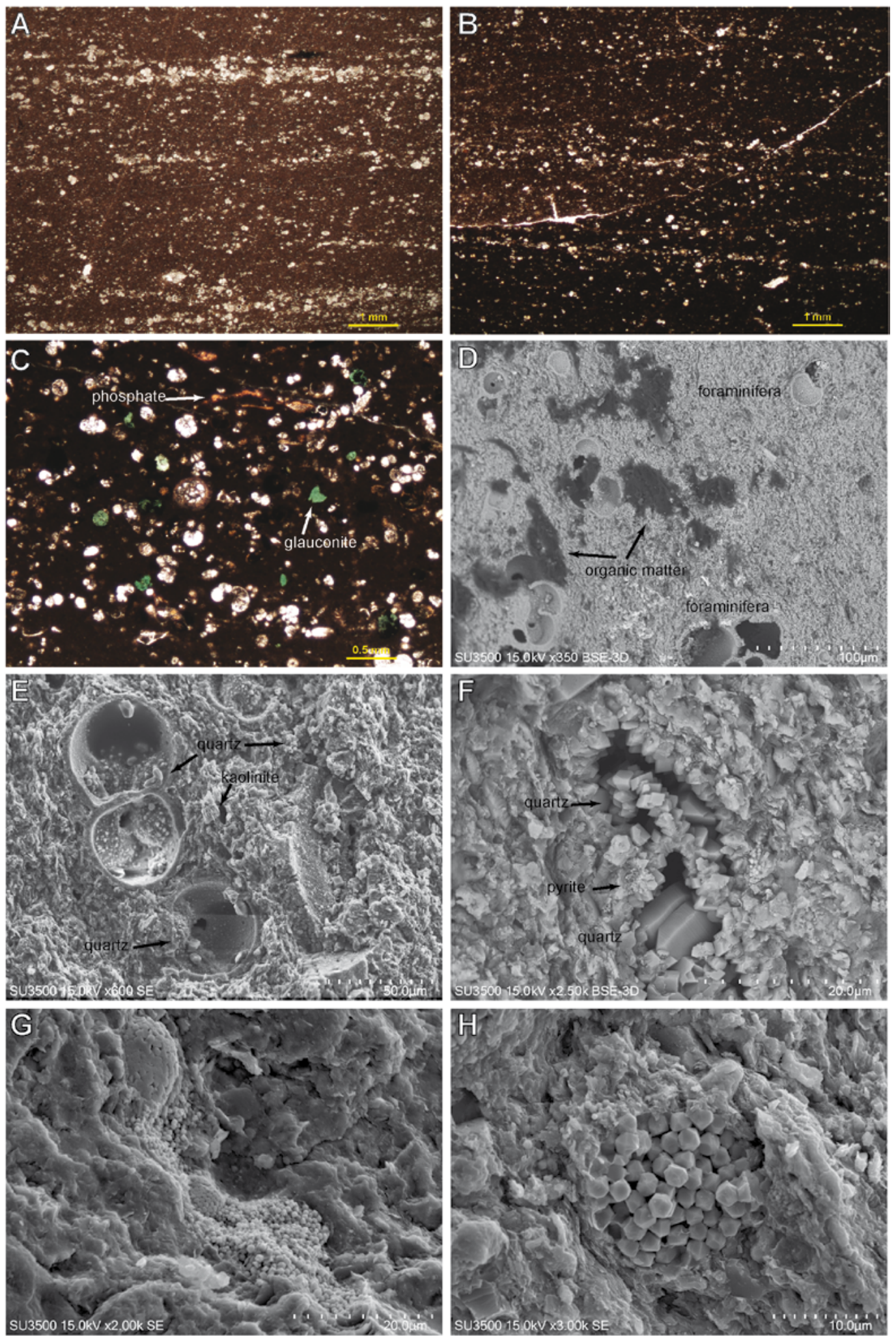

FIGURE 5. Photomicrographs of selected samples showing petrographic features: A-C) thin-section photomicrographs of major Pabdeh BSU facies in the studied wells; A) RR-3215m, skeletal debris, planktonic foraminifera, laminated wackestone-packstone; B) KR-2608m, laminated planktonic foraminifera wackestone-packstone; C) KR-2608m, wackestone with glauconite, phosphatic grains and organic matter; D-H) SEM (SE and BSE) photomicrographs of selected samples; D) RS-2307m, skeletal-debris of planktonic foraminifera with an abundance of organic matter; E) KR-2608m, skeletal-debris of planktonic foraminifera filled with authigenic quartz; F) RR-3223m, moldic pore largely filled by authigenic quartz; G) GS-3510m; H) RR-3223m, pyrite framboids. 

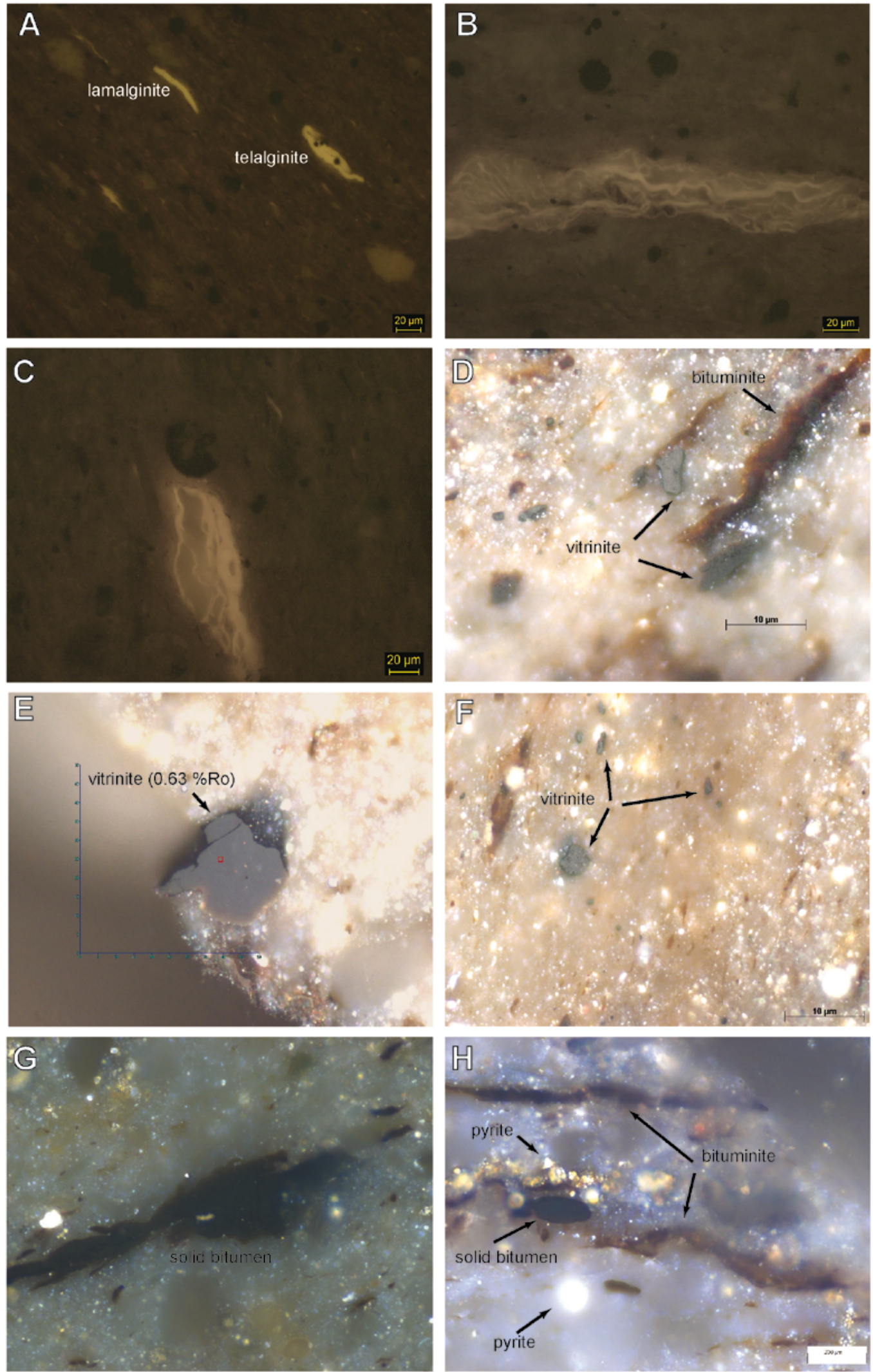

FIGURE 6. Photomicrographs taken under incident white light and blue-light excitation on the studied samples from the Pabdeh BSU: images were captured under an oil-immersion objective with 100X magnification; A-C) liptinite (telalginite and lamalginite) with amorphous organic matter; D-F) vitrinite particles with bitumen staining associated with abundance of pyrite mineral; G-H) solid bitumen and bituminite associated with abundance of pyrite mineral.GS-3510m; H) RR-3223m, pyrite framboids. 
TABLE 1. Mineralogical composition (wt.\%) of Pabdeh BSU

\begin{tabular}{|c|c|c|c|c|c|c|c|c|c|c|c|c|c|}
\hline Well & $\begin{array}{l}\text { Depth } \\
(\mathrm{m})\end{array}$ & Quartz & Calcite & Dolomite & Ankerite & Plagiodase & $\begin{array}{c}\text { K- } \\
\text { Feldspar }\end{array}$ & Smectite & Kaolinite & Muscovite & $\begin{array}{c}\text { Illite/ } \\
\text { Smectite }\end{array}$ & Chlorite & Pyrite \\
\hline \multirow{9}{*}{ GS } & 2479 & 9.36 & 45.82 & 2.35 & 5.62 & & & & 19.62 & 1.71 & 13.28 & 1.26 & 0.98 \\
\hline & 2494 & 13.84 & 52.25 & 1.96 & 2.59 & & & & 14.06 & 1.21 & 12.92 & & 1.15 \\
\hline & 2510 & 20.60 & 51.07 & 0.90 & 1.38 & & & & 8.83 & 2.68 & 12.95 & & 1.58 \\
\hline & 2524 & 17.28 & 41.04 & & 0.50 & & & & 9.38 & 4.82 & 23.78 & & 3.17 \\
\hline & 2540 & 9.00 & 63.18 & 1.09 & 1.14 & & & & 13.24 & 2.95 & 8.08 & & 1.30 \\
\hline & 2554 & 35.10 & 39.63 & 1.61 & 2.22 & & & & 6.39 & 1.40 & 12.73 & 0.10 & 0.82 \\
\hline & 2568 & 26.68 & 49.05 & 0.84 & 0.19 & & & & 8.68 & 2.01 & 11.26 & 0.26 & 1.04 \\
\hline & 2587 & 6.10 & 64.77 & 2.11 & 4.05 & & & & 7.54 & & 14.69 & & 0.73 \\
\hline & 2606 & 6.35 & 71.55 & 0.55 & 1.78 & & & & 10.30 & 1.57 & 6.20 & 1.00 & 0.71 \\
\hline \multirow{7}{*}{$\mathrm{KR}$} & 2600 & 8.81 & 51.19 & 0.55 & 4.59 & & & & 19.44 & 2.24 & 12.28 & & 0.89 \\
\hline & 2618 & 10.91 & 51.67 & 2.42 & 1.90 & & & & 9.54 & 2.77 & 18.70 & & 2.09 \\
\hline & 2640 & 17.70 & 48.67 & 3.04 & 1.98 & & & & 6.26 & 3.31 & 17.55 & 0.26 & 1.22 \\
\hline & 2660 & 33.69 & 42.94 & 2.02 & 2.47 & & & & 3.42 & 2.17 & 12.45 & & 0.83 \\
\hline & 2676 & 29.03 & 50.36 & 2.80 & 1.25 & & & & 2.06 & 1.95 & 11.77 & & 0.77 \\
\hline & 2694 & 9.29 & 61.97 & 1.29 & 5.16 & & & & 0.00 & 3.26 & 18.29 & & 0.74 \\
\hline & 2710 & 7.88 & 39.15 & 3.11 & 6.19 & & & & 12.59 & 5.58 & 24.03 & & 1.48 \\
\hline \multirow{10}{*}{ RR } & 3190 & 4.66 & 46.05 & 1.15 & 4.05 & & & & 16.58 & 2.30 & 24.22 & 0.00 & 1.00 \\
\hline & 3203 & 3.93 & 30.55 & 1.04 & 5.04 & & 0.83 & & 30.92 & 1.24 & 23.77 & 1.13 & 1.54 \\
\hline & 3220 & 11.31 & 53.03 & 0.17 & 1.67 & & 0.83 & & 16.19 & 1.61 & 13.41 & 0.22 & 1.56 \\
\hline & 3230 & 16.48 & 44.22 & 1.15 & & & & & 13.04 & 2.10 & 21.09 & & 1.87 \\
\hline & 3240 & 10.37 & 51.89 & 0.54 & & & & & 15.87 & 2.50 & 16.06 & 1.20 & 1.49 \\
\hline & 3255 & 12.20 & 49.44 & 0.70 & 0.13 & & & 4.84 & 13.75 & 0.89 & 16.75 & & 1.28 \\
\hline & 3270 & 27.49 & 38.90 & 0.14 & 0.42 & & & 3.70 & 11.89 & 1.33 & 14.67 & & 1.46 \\
\hline & 3283 & 12.23 & 52.05 & 1.59 & 1.43 & & & 2.42 & 14.09 & 2.98 & 12.23 & & 0.99 \\
\hline & 3298 & 5.07 & 61.25 & 0.73 & 1.01 & & & & 22.33 & 0.80 & 8.15 & & 0.66 \\
\hline & 3312 & 11.29 & 59.57 & & 0.14 & & & & 10.00 & 0.52 & 12.16 & 5.75 & 0.56 \\
\hline \multirow{8}{*}{ RS } & 2252 & 7.23 & 54.42 & 0.75 & 2.11 & 2.38 & & & 14.14 & 1.34 & 16.09 & 1.13 & 0.40 \\
\hline & 2270 & 11.64 & 54.95 & 1.57 & 4.77 & & & & 11.26 & 2.23 & 12.22 & & 1.37 \\
\hline & 2285 & 15.82 & 60.33 & 1.89 & 1.56 & & & & 9.92 & 3.19 & 5.94 & 0.14 & 1.22 \\
\hline & 2305 & 11.50 & 65.95 & 0.92 & 0.25 & & & & 8.04 & 2.64 & 8.71 & 0.56 & 1.43 \\
\hline & 2320 & 22.87 & 55.94 & 5.52 & 2.96 & & & & 4.44 & 2.51 & 4.72 & & 1.04 \\
\hline & 2335 & 15.80 & 59.48 & 2.57 & 0.15 & & & & 8.94 & 2.17 & 10.13 & & 0.76 \\
\hline & 2349 & 3.53 & 58.86 & 3.89 & 6.15 & & & & 9.01 & 0.33 & 16.94 & & 1.29 \\
\hline & 2363 & 4.9 & 70.11 & 7.55 & 7.88 & & & & & 3.46 & 5.37 & & 0.74 \\
\hline
\end{tabular}

the presence of autochthonous vitrinite particles. Vitrinite reflectance show low variation, ranging from 0.3 to $0.53 \%$ for wells RR and RS and from $0.5 \%$ to $0.67 \%$ for wells GS and KR (Table I), indicate a relatively low level of thermal maturity (immature to early stage of oil window). This is in agreement with the thermal maturity trend inferred from Rock-Eval $\mathrm{T}_{\max }$ values.

\section{Molecular composition}

Biomarker parameters have been used effectively for assessing the thermal maturity of crude oil and source rock as well as characterizing the depositional environment and source input of organic matter (Peters et al., 2005). Isoprenoids, $n$-alkanes and saturate biomarker parameters (sterane and hopane) are presented in Table 2 for samples from the BSU. Total Ion Chromatograms (TIC) for the samples indicate a unimodal distribution of $n$-alkanes with a clear dominance of short-chain $n$-alkanes $\left(\mathrm{C}_{15}\right.$ to $\left.\mathrm{C}_{20}\right)$ relative to long-chain n-alkanes (Fig. 7). The Carbon Preference Index (CPI) values of the studied samples range from 0.7 to 1.3 , indicating slightly even-carbon predominance $(\mathrm{CPI}<1)$. The acyclic isoprenoid pristane/phytane ratios vary between 0.5 and 1, with an exception for KR (0.32) and RR (1.3) 
TABLE 2. Selected biomarker parameters of the analysed samples in the Pabdeh BSU

\begin{tabular}{|c|c|c|c|c|c|c|c|c|c|c|c|c|c|c|c|c|c|c|c|c|}
\hline $\begin{array}{l}\text { WELL } \\
\text { NO. }\end{array}$ & $\begin{array}{c}\text { DEPTH } \\
(\mathrm{m})\end{array}$ & $\mathrm{Pr} / \mathrm{Ph}$ & $\mathrm{Pr} / \mathrm{C}_{17}$ & $\mathrm{Ph} / \mathrm{C}_{18}$ & CPI & $\% \mathrm{C}_{27}$ & $\% \mathrm{C}_{28}$ & $\% \mathrm{C}_{29}$ & $\begin{array}{c}\mathrm{C}_{27} \\
\mathrm{Dia} / \\
\text { (Dia+Reg) }\end{array}$ & $\begin{array}{c}C_{29} \\
\beta \beta / \\
(\beta \beta+\alpha \alpha)\end{array}$ & $\begin{array}{c}\mathrm{C}_{29} \\
20 \mathrm{~S} / \\
(\mathrm{S}+\mathrm{R})\end{array}$ & $\mathrm{St} / \mathrm{H}$ & $\begin{array}{c}\mathrm{Ts} / \\
(\mathrm{Ts}+\mathrm{Tm})\end{array}$ & $\begin{array}{l}\mathrm{C}_{29} \mathrm{H} / \\
\mathrm{C}_{30} \mathrm{H}\end{array}$ & $\begin{array}{l}\mathrm{Ole/} \\
\mathrm{Ole}+ \\
\mathrm{C}_{30} \mathrm{H}\end{array}$ & $\begin{array}{c}\mathrm{C}_{31} \\
/ \mathrm{C}_{30} \mathrm{H}\end{array}$ & $\begin{array}{l}\mathrm{C}_{32} \mathrm{~S} / \\
(\mathrm{S}+\mathrm{R})\end{array}$ & $\begin{array}{c}\mathrm{G} / \\
\mathrm{C}_{30} \mathrm{H}\end{array}$ & $\begin{array}{l}\text { Mor/ } \\
\mathrm{C}_{30} \mathrm{H}\end{array}$ & $\begin{array}{l}\mathrm{C}_{35} \mathrm{I} \\
\mathrm{C}_{34}\end{array}$ \\
\hline \multirow{5}{*}{ GS } & 2506 & 0.88 & 0.47 & 0.84 & 0.89 & 36.63 & 29.61 & 33.76 & 0.29 & 0.4 & 0.35 & 1.78 & 0.35 & 0.49 & 0.52 & 0.30 & 0.57 & 0.06 & 0.12 & 1.12 \\
\hline & 2514 & 0.50 & 1.21 & 0.95 & 0.7 & 33.10 & 32.64 & 34.26 & 0.31 & 0.46 & 0.44 & 0.81 & 0.31 & 0.44 & 0.16 & 0.37 & 0.55 & 0.10 & 0.16 & 0.66 \\
\hline & 2521 & 0.51 & 1.14 & 1.18 & 0.75 & 31.46 & 33.23 & 35.31 & 0.33 & 0.49 & 0.45 & 0.87 & 0.31 & 0.44 & 0.15 & 0.42 & 0.56 & 0.09 & 0.13 & 1.04 \\
\hline & 2532 & 0.54 & 1.16 & 1.03 & 0.77 & 30.84 & 33.04 & 36.12 & 0.30 & 0.5 & 0.46 & 0.86 & 0.31 & 0.49 & 0.13 & 0.41 & 0.56 & 0.10 & 0.15 & 1.00 \\
\hline & 2549 & 0.72 & 0.82 & 0.78 & 0.85 & 30.32 & 31.64 & 38.04 & 0.40 & 0.51 & 0.45 & 0.74 & 0.44 & 0.70 & 0.18 & 0.43 & 0.56 & 0.11 & 0.15 & 0.97 \\
\hline \multirow{5}{*}{$K R$} & 2600 & 0.91 & 0.96 & 0.75 & 0.97 & 27.74 & 37.52 & 34.74 & 0.31 & 0.57 & 0.51 & 0.81 & 0.40 & 0.63 & 0.20 & 0.40 & 0.56 & 0.05 & 0.10 & 0.73 \\
\hline & 2608 & 0.64 & 0.86 & 0.84 & 0.80 & 28.00 & 37.13 & 34.88 & 0.23 & 0.56 & 0.48 & 0.83 & 0.37 & 0.57 & 0.29 & 0.45 & 0.57 & 0.07 & 0.11 & 0.96 \\
\hline & 2618 & 0.78 & 0.42 & 0.69 & 0.90 & 34.24 & 33.11 & 32.65 & 0.17 & 0.70 & 0.52 & 0.73 & 0.29 & 0.60 & 0.15 & 0.40 & 0.60 & $\mathrm{NF}$ & 0.07 & 0.67 \\
\hline & 2636 & 0.32 & 0.4 & 0.42 & 0.90 & 31.40 & 32.60 & 36.00 & 0.32 & 0.55 & 0.49 & 0.56 & 0.31 & 0.47 & 0.11 & 0.35 & 0.59 & 0.04 & 0.08 & 0.85 \\
\hline & 2656 & 0.72 & 0.85 & 1.28 & 0.78 & 32.62 & 29.50 & 37.88 & 0.23 & 0.70 & 0.48 & 0.78 & 0.35 & 0.51 & 0.21 & 0.30 & 0.59 & 0.05 & 0.06 & 0.88 \\
\hline \multirow{5}{*}{$R R$} & 3208 & 1.30 & 1.00 & 0.96 & 1.29 & 35.23 & 32.15 & 32.63 & 0.31 & 0.18 & 0.08 & 0.56 & 0.32 & 0.65 & 0.29 & 0.33 & 0.42 & 0.13 & 0.25 & 0.71 \\
\hline & 3224 & 0.91 & 1.55 & 1.62 & 0.78 & 35.55 & 29.93 & 34.52 & 0.23 & 0.35 & 0.07 & 2.1 & 0.34 & 0.47 & 0.2 & 0.37 & 0.33 & 0.19 & 0.25 & 1.4 \\
\hline & 3242 & 1.0 & 1.68 & 0.49 & 1.03 & 36.97 & 31.02 & 32.01 & 0.27 & 0.25 & 0.18 & 1.25 & 0.32 & 0.60 & 0.16 & 0.38 & 0.48 & 0.09 & 0.19 & 0.94 \\
\hline & 3256 & 0.73 & 0.71 & 1.20 & 0.88 & 33.30 & 31.30 & 35.40 & 0.12 & 0.39 & 0.05 & 3.18 & 0.24 & 0.41 & 0.10 & 0.41 & 0.28 & 0.26 & 0.29 & 1.20 \\
\hline & 3275 & 1.0 & 0.67 & 0.92 & 1.2 & 31.53 & 34.21 & 34.26 & 0.22 & 0.28 & 0.09 & 1.42 & 0.35 & 0.49 & 0.48 & 0.37 & 0.42 & 0.14 & 0.23 & 1.49 \\
\hline \multirow{4}{*}{$R S$} & 2279 & 0.88 & 0.96 & 0.57 & 0.76 & 39.00 & 26.00 & 35.00 & 0.18 & 0.32 & 0.11 & 1.23 & 0.42 & 0.42 & 0.13 & 0.42 & 0.43 & 0.19 & 0.23 & 1.27 \\
\hline & 2304 & 0.82 & 0.88 & 0.81 & 0.78 & 35.00 & 26.48 & 38.52 & 0.30 & 0.40 & 0.27 & 0.99 & 0.37 & 0.54 & 0.10 & 0.49 & 0.51 & 0.17 & 0.21 & 1.44 \\
\hline & 2323 & 0.78 & 1.76 & 1.50 & 0.85 & 30.71 & 33.00 & 36.29 & 0.29 & 0.34 & 0.26 & 1.16 & 0.39 & 0.40 & 0.11 & 0.44 & 0.50 & 0.17 & 0.24 & 1.56 \\
\hline & 2341 & 0.52 & 0.45 & 0.60 & 1.10 & 36.00 & 31.00 & 33.00 & 0.31 & 0.40 & 0.29 & 1.29 & 0.26 & 0.51 & 0.43 & 0.44 & 0.55 & 0.04 & 0.25 & 1.06 \\
\hline & $\begin{array}{l}\text { Pr/Ph= Pris } \\
\mathrm{CPI}=\text { Carbo } \\
\% \mathrm{C}_{27}=\text { Ste } \\
\% \mathrm{C}_{28}=\text { Ste } \\
\% \mathrm{C}_{29}=\mathrm{Ste} \\
\mathrm{C}_{27} \mathrm{Dia} /(\mathrm{Di} \\
+\mathrm{C}_{29} \text { ada } 2 \\
\mathrm{C}_{22} \mathrm{H} / \mathrm{C}_{30} \mathrm{H}= \\
22 \mathrm{~S} /\left(\mathrm{C}_{32} 22\right.\end{array}$ & $\begin{array}{l}\text { tane/Phy } \\
\text { on prefere } \\
\text { rane } C_{27} \\
\text { rane } C_{28} \\
\text { rane } C_{29} \\
\text { a+Reg) } \\
\text { +RR) sterz } \\
=\mathrm{C}_{29} 30-n\end{array}$ & 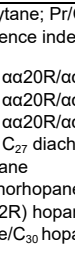 & $\begin{array}{l}\mathrm{C}_{17}=\text { Prist } \\
\mathrm{x}=2\left(\mathrm{C}_{23}\right. \\
\\
\left(\mathrm{C}_{27} 20 \mathrm{R}\right. \\
\left(\mathrm{C}_{27} 20 \mathrm{R}\right. \\
\left(\mathrm{C}_{27} 20 \mathrm{R}\right.\end{array}$ & $\begin{array}{l}\mathrm{ne} / \mathrm{C}_{17} n \\
\mathrm{C}_{25}+\mathrm{C} \\
\mathrm{C}_{28} 20 \mathrm{R} \\
\mathrm{C}_{28} 20 \mathrm{R} \\
\mathrm{C}_{82} \mathrm{OR}\end{array}$ & $\begin{array}{l}\text { alkane; } P \\
\left.+C_{29}\right) /[ \\
+C_{29} 20 R \\
+C_{29} 20 R \\
+C_{22} 20 R\end{array}$ & $\begin{array}{l}\mathrm{C}_{18}=\mathrm{Pl} \\
22+2\left(\mathrm{C}_{2}\right. \\
\times 100 \% \\
\times 100 \% \\
\times 100 \%\end{array}$ & $\begin{array}{l}\text { tane/ } / C_{18} \\
+C_{26}+C\end{array}$ & $\begin{array}{l}\text { 8a-trisnorhop } \\
=\mathrm{C}_{31} \text { regular }\end{array}$ & $\begin{array}{l}\text { ane }+17 \text { a-tr } \\
\text { homohopan }\end{array}$ & $\begin{array}{l}\text { norhopan } \\
/ \mathrm{C}_{30} \text { hopa }\end{array}$ & $\begin{array}{l}\mathrm{C}_{35} / \mathrm{C} \\
; \text { Ole// }\end{array}$ & $\begin{array}{l}{ }_{4} \mathrm{H}=\mathrm{C}_{35} \text { hor } \\
\mathrm{le}+\mathrm{C}_{30} \mathrm{H}=\mathrm{C}\end{array}$ & $\begin{array}{l}\text { ohopane } \\
\text { eanane/c }\end{array}$ & $\begin{array}{l}2 \mathrm{~S} / \mathrm{C}_{34} \text { ho } \\
\text { anane }+\mathrm{C}_{3}\end{array}$ & $\begin{array}{l}\text { Iohopane } \\
\text { hopane }\end{array}$ & $22 \mathrm{~S} ; \mathrm{C}_{3}$ & $/(\mathrm{S}+\mathrm{R})=$ & $C_{32}$ & \\
\hline
\end{tabular}

samples. The ratios of $\mathrm{Pr} / n-\mathrm{C}_{17}$ and $\mathrm{Ph} / n-\mathrm{C}_{18}$ range from 0.4 to 1.9 and from 0.42 to 1.6 , respectively (Table 2).

Terpane distributions are characterized by a high content of pentacyclic terpanes compared to tricyclic and tetracyclic terpanes (Fig. 8). The most abundant hopane peak is $\mathrm{C}_{30^{-}}$ hopane in all the studied samples. The relative abundance of $\mathrm{C}_{29}$ to $\mathrm{C}_{30}$ hopane is generally similar in all samples with values between 0.4 to 0.7 . The $\mathrm{Ts} /(\mathrm{Ts}+\mathrm{Tm})$ ratio for all samples is below 0.44 (Table 2). Oleanane was detected in all the samples at varying concentration (Fig. 8). The oleanane index varies between $10 \%$ to $48 \%$, with maximum values for GS and RR samples (Table 2). Gammacerane is also traced, although in low abundance (gammacerane/hopane ratio ranges from 0.04 to 0.26 ) (Table 2). Generally, the studied samples show relatively similar profiles of regular sterane distributions (Fig. 9). Diasteranes are present at low quantities in all the analyzed samples (Table 2).

\section{DISCUSSION}

\section{Hydrocarbon generation potential and organic matter type}

The amount of hydrocarbons produced during pyrolysis $\left(\mathrm{S}_{2}\right)$ is an important parameter to evaluate the generation potential of source rocks (Peters and Casa, 1994). Higher $\mathrm{S}_{2}$ values are in accordance with higher $\mathrm{HI}$ values and TOC contents in the studied samples. Plots of the generation potential $\left(S_{I}+S_{2}\right)$ versus TOC indicate that the entire sections in all four wells have good to excellent oil generation potential (Fig. 10).

The organic matter type could be characterized by HI values (Hunt, 1996). Values higher than $300 \mathrm{mg} \mathrm{HC} / \mathrm{g}$ TOC could indicate Type I and II kerogen, which are derived from lacustrine or marine source rocks (Dembicki, 2009; Hunt, 1996). Samples of the BSU indicate values between 400 to $650 \mathrm{mg} \mathrm{HC} / \mathrm{g}$ TOC (Table I), consistent with Type II kerogen. Furthermore, the plotting data of $S_{2}$ versus TOC could also supports that the BSU predominantly contains Type II organic matter (Fig. 11A). The plot of HI versus $\mathrm{T}_{\max }$ is used to determine the kerogen type and maturity (Peters and Casa, 1994; Tissot and Welte, 1984). Based on this diagram, samples of the BSU contain Type II organic matter, although a few samples are located in Type II-III kerogen area for well RR (Fig. 11B). The lower HI value for some samples of RR well implicates the contribution of terrigenous organic matter. This conclusion is further supported by the organic petrographic results indicating a relatively higher contribution of vitrinite/intertinite macerals in well RR relative to other wells.

\section{Depositional environment}

The distribution of $n$-alkanes in crude oils and source extracts can provide useful information about the sources 

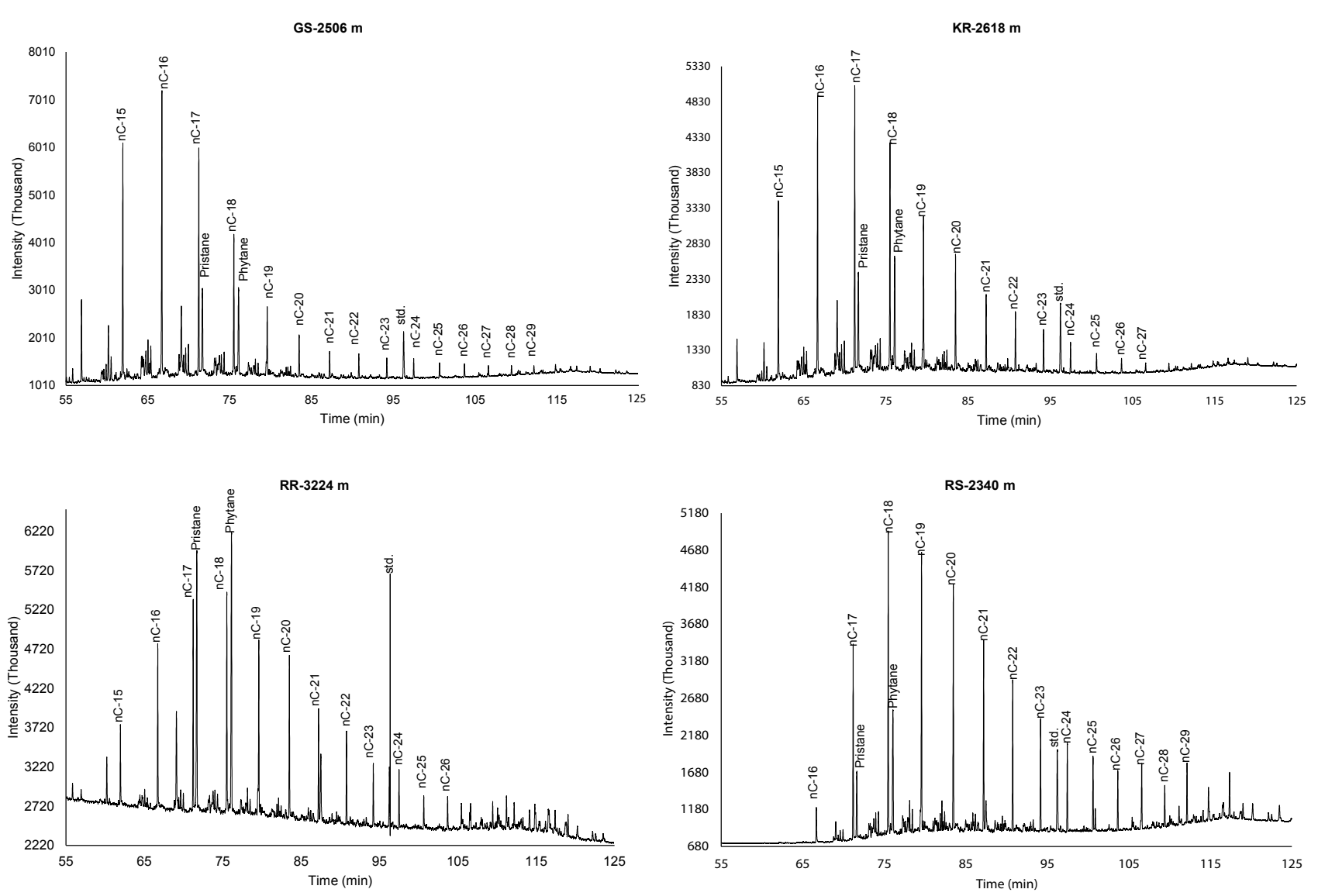

FIGURE 7. Chromatograms of the saturate hydrocarbon fractions related to selected samples of the Pabdeh BSU.

of the organic matter (Peters et al., 2005). Unimodal distribution and predominance of short-chain $n$-alkanes for all the studied samples (Fig. 7), could imply a marine environment with high contribution of aquatic organic matter (Ghassal et al., 2016; Peters et al., 2005). Moreover, the low abundance of the long-chain n-alkane $\left(n-\mathrm{C}_{22+}\right)$ and the slight even carbon preference $(\mathrm{CPI} \leq 1)$ indicate the predominance of marine with minor terrigenous organic matter input into depositional environment (Peters et al., 2005). Pristane originates from phytol by oxidation and decarboxylation, and phytane by dehydration and reduction (Peters et al., 2005). Overall, except for one sample from well RR, all samples have pristane/phytane ( $\mathrm{Pr} / \mathrm{Ph})$ values less than 1 , indicating that the organic matter was mainly deposited under anoxic condition (Peters et al., 2005). This is in accordance with the cross plot of the $\mathrm{Pr} / n-\mathrm{C}_{17}$ versus $\mathrm{Ph} / n-\mathrm{C}_{18}$ (Fig. 12), which shows that the studied samples contain Type II organic matter deposited under reducing conditions (Fig. 12).

Oleanane in crude oils and source extracts is an important marker for both source input and geological age. This compound is originated from Cretaceous or younger, higher plants, which is in agreement with the geological age of the studied samples (Peters et al., 2005). The oleanane index for samples from the BSU varies from $10 \%$ to $48 \%$ (Table 2). The high abundance of oleanane for some samples may be related to periodically high terrigenous input into the environment (Peters et al., 2005). The gammacerane content is an indicator of water salinity and water stratification in a sedimentary environment (Moldowan et al., 1986). The gammacerane/hopane ratio ranges from 0.04 to 0.26 , suggesting that the BSU was mainly deposited in a stratified water environment. A relatively high salinity is suggested for the depositional environment by the high pregnane concentrations in the studied extracts (Fig. 9). The $\mathrm{C}_{31}$-22R-hopane/ $\mathrm{C}_{30}$-hopane ratio is generally higher than 0.25 for marine environments, whereas values lower than 0.25 point to lacustrine settings (Peters et al., 2005). For all the samples, the $\mathrm{C}_{31} 22 \mathrm{R}$ homohopane $/ \mathrm{C}_{30} \alpha(\mathrm{H})$-hopane ratios is higher than 0.25 (Table 2), indicating that the organic-rich BSU was deposited in a marine environment. Moreover, the $\mathrm{C}_{35} / \mathrm{C}_{34}$ homohopane ratios obtained for most of the analyzed samples are above 0.80 , suggesting that the organic matter was deposited in a marine environment under anoxic conditions (Mello et al., 1988). 

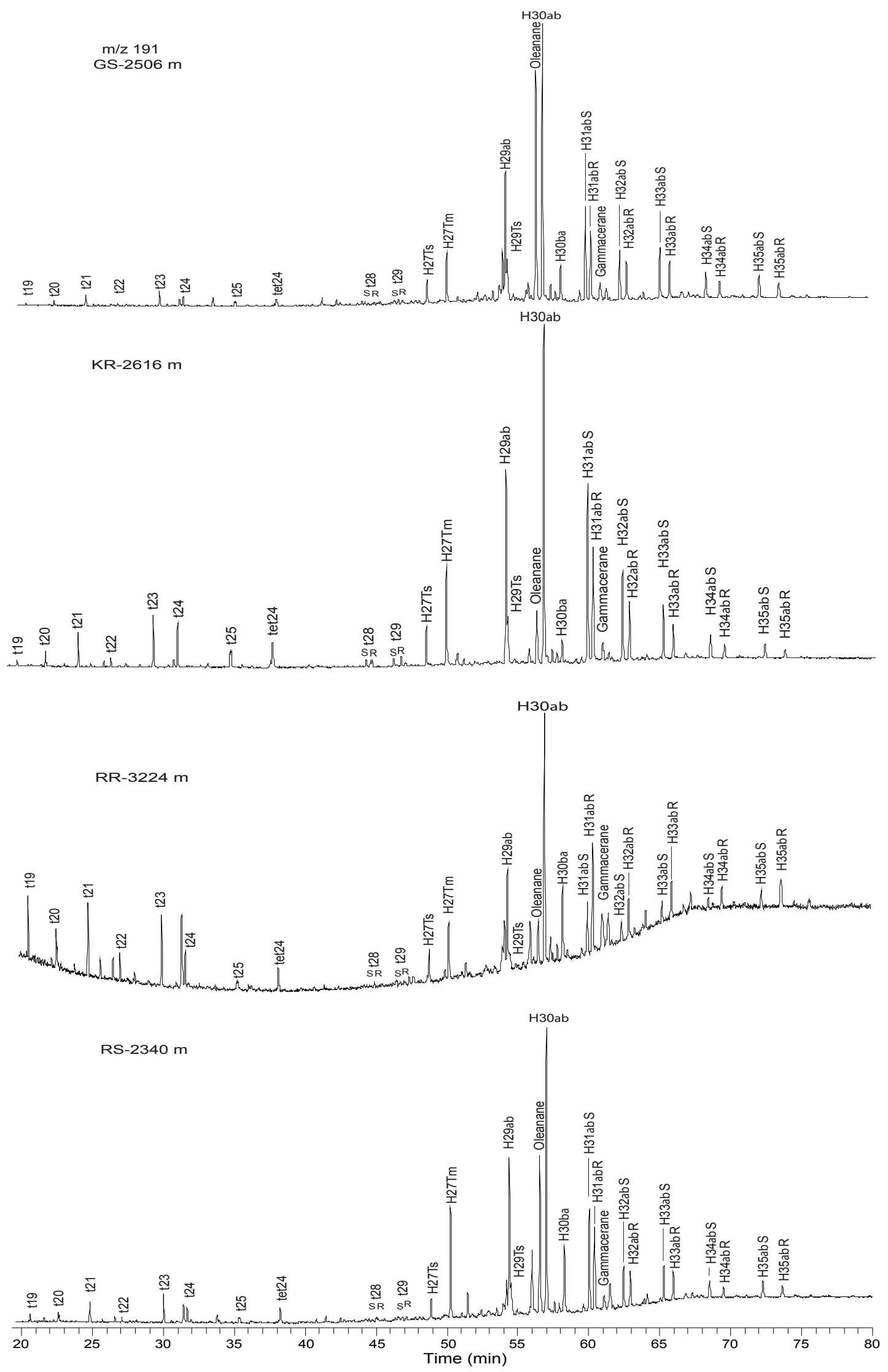

FIGURE 8. Selected mass chromatograms of the hopane biomarker (m/z 191) for the Pabdeh BSU in the studied wells. 

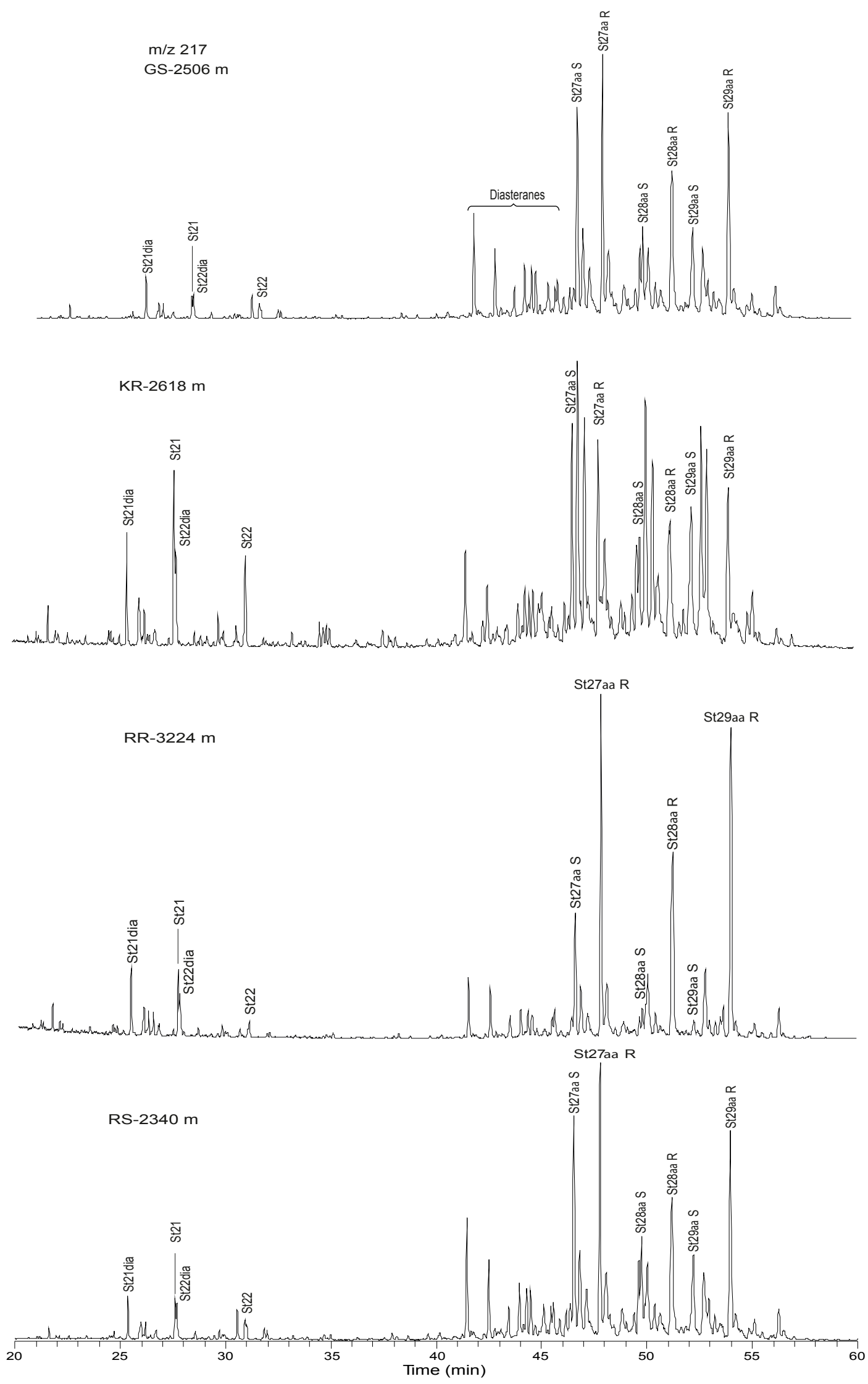

FIGURE 9. Selected mass chromatograms of the sterane biomarker $(\mathrm{m} / \mathrm{z} 217)$ for the Pabdeh BSU in the studied wells. 


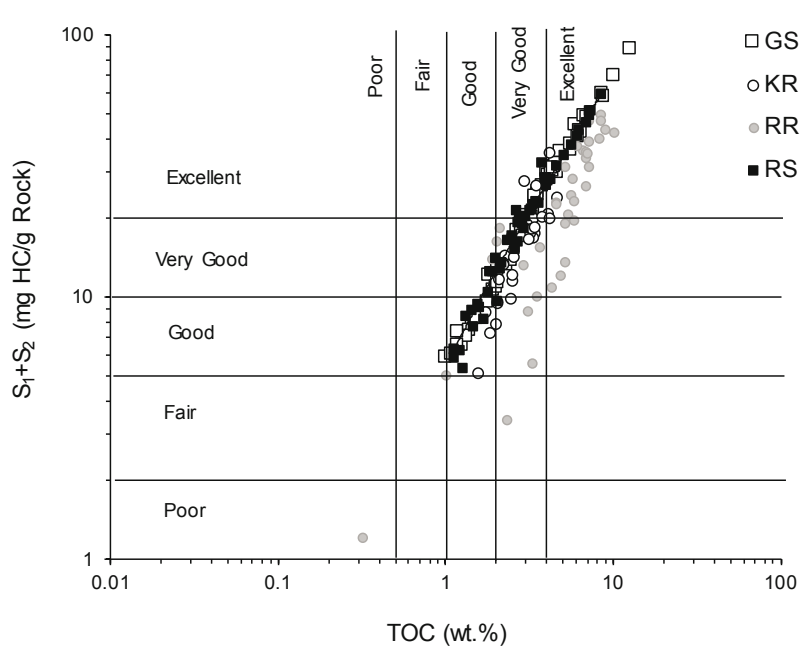

FIGURE 10. TOC vs. generation potential $\left(S_{1}+S_{2}\right)$ diagram, showing a good to excellent hydrocarbon generation potential for the Pabdeh BSU in the studied wells (after Dembicki, 2009).

The sterane composition can be used to characterize the depositional environment, organic matter input and the maturation range of potential source rocks (Seifert and Moldowan, 1977). The relative abundance of $\mathrm{C}_{27}-\mathrm{C}_{29}$ regular steranes is used to indicate the source of organic matter (Huang and Meinschein, 1979). High relative abundance of $\mathrm{C}_{27}, \mathrm{C}_{28}$ and $\mathrm{C}_{29}$ steranes is due to marine phytoplankton and algae, lacustrine algae and terrigenous higher plants, respectively (Moldowana and Seifert, 1985). A ternary plot of $\mathrm{C}_{27}-\mathrm{C}_{29}$ sterane distribution of samples from the BSU shows a slightly higher relative abundance of $\mathrm{C}_{27}$ and $\mathrm{C}_{29}$ steranes compared to the $\mathrm{C}_{28}$ sterane (Fig. 13). This suggests predominantly marine conditions with high algal input and minor contribution of terrigenous higher plants in agreement with the organic petrographic inspections. Diasteranes/steranes ratio is commonly used as an indicator of the redox conditions in the depositional environment (Peters et al., 2005). Samples in this study have low diasterane/sterane ratios (ranging between 0.17 to 0.4 ), suggesting anoxic clay-poor or carbonate source rock (Peters et al., 2005). Regular steranes/17 $\alpha$-hopanes ratio represents input of eukaryotic (mainly algae and plankton) versus prokaryotic (bacteria) organic matter to the sedimentary environment of source rocks (Peters et al., 2005; Moldowan et al., 1986). Varying sterane/hopane ratios obtained for the studied samples (ranges from 0.4 to 3.18) may indicate periodic variations in marine organic matter input (from planktonic and algae to bacteria). Conclusions from biomarker parameters are consistent with organic petrographic observations stated earlier (i.e. significant amount of liptinite and amorphous organic matter, high abundance of pyrite framboids, phosphatic and glauconite grains). These are in agreement with reducing marine settings during deposition of the Pabdeh BSU.

\section{Thermal maturity}

Thermal maturity of the organic matter contained within the BSU has been assessed using vitrinite reflectance (\%Ro), pyrolysis $\mathrm{T}_{\max }$ and Production Index (PI) values, and saturate biomarkers (Tables I; 2). The $\mathrm{T}_{\max }$ values of studied samples indicate that the organic matter at wells RR and RS is immature (i.e. mostly below $425^{\circ} \mathrm{C}$ ). In contrast, samples from wells $\mathrm{KR}$ and $\mathrm{GS}$ have higher $\mathrm{T}_{\max }$ values (i.e. ranging between 425 to $435^{\circ} \mathrm{C}$ ), which suggest marginally-mature to mature state (Fig. 11B). The pattern of variation in PI data (ranging from 0.011 to 0.3 , Table I) are in agreement with the $\mathrm{T}_{\max }$ values. Thermal maturity trends are also assessed by vitrinite reflectance measurements being considered the most reliable maturity indicator for sedimentary organic matter (Dow, 1977). A thermally immature to early mature state is suggested for the BSU at wells RR and RS (RO values ranging from 0.42 to $0.5 \%$ ). In contrast, reflectance values range from 0.5 to $0.67 \%$ for wells KR and GS (Table I). The same results are suggested by vitrinite reflectance estimated from $\mathrm{T}_{\max }$ (Jarvie et al., 2001), which shows values of $0.33-0.65 \%$ Ro consistent with immature to early mature stages. However, one should bear in mind that the true maturity of the studied interval may be slightly higher since both maturity parameters might be suppressed due to the presence of a significant amount of hydrogen-rich liptinite macerals and bitumen impregnation (Hackley and Cardott, 2016; Hutton and Cook, 1980).

Several biomarker maturity indicators have been applied to evaluate thermal maturity of the BSU. Generally, the relatively higher abundance of $n$-alkanes in the biomarker region of obtained gas chromatograms is consistent with lower level of thermal maturation for RR and RS wells (Fig. 7). The $\mathrm{C}_{32}$ homohopane $22 \mathrm{~S} /(22 \mathrm{~S}+22 \mathrm{R})$ rises up to 0.6 , while 0.57 to 0.62 is the equilibrium range during maturation corresponding to the onset of oil generation (Mackenzie et al., 1980; Seifert and Moldowan, 1980). The $\mathrm{C}_{32}$ homohopane $22 \mathrm{~S} /(22 \mathrm{~S}+22 \mathrm{R})$ ratio of the studied samples from $\mathrm{RR}$ and RS wells are low, varying from 0.28 to 0.48 and from 0.43 to 0.55 , respectively. Thus, these samples are immature at these locations. In contrast, the studied samples from KR and GS wells have relatively higher $\mathrm{C}_{32}$ homohopane $22 \mathrm{~S} /(22 \mathrm{~S}+22 \mathrm{R})$ ratios, suggesting that the samples are immature at these locations. In contrast, the BSU samples from KR and GS wells have relatively higher $\mathrm{C}_{32}$ homohopane $22 \mathrm{~S} /(22 \mathrm{~S}+22 \mathrm{R})$ ratios, suggesting that the organic matter from these wells are thermally mature and have reached the equilibrium stage (Table 2). The $\mathrm{C}_{29} 20 \mathrm{~S} /(20 \mathrm{~S}+20 \mathrm{R})$ and $\beta \beta /(\alpha \alpha+\beta \beta)$ sterane ratios are particularly effective for thermal maturity of source rocks at the beginning of the oil window (Seifert and Moldowan, 1986). The ratio of $\mathrm{C}_{29} 20 \mathrm{~S} /(20 \mathrm{~S}+20 \mathrm{R})$ rises from 0 to 0.5 (equilibrium $=0.52-0.55$ ) with maturity, while the ratio of $\beta \beta /(\alpha \alpha+\beta \beta)$ increases from near-zero to 0.7 (equilibrium $=0.67-0.7)($ Peters et al., 2005). Based on 

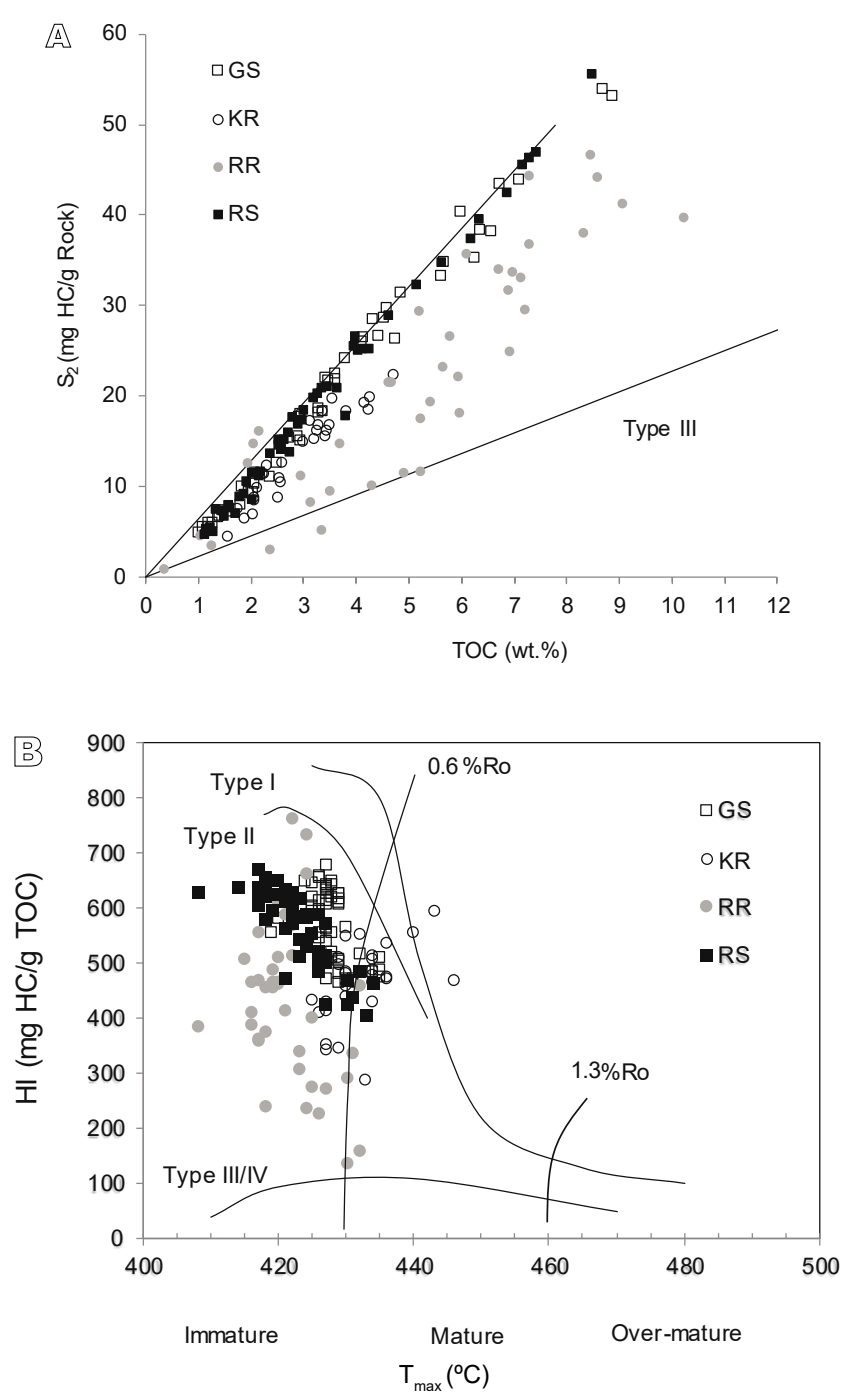

FIGURE 11. A) TOC vs. $S_{2}$ and B) HI vs. $T_{\max }$ diagrams, indicating Type II kerogen for the Pabdeh BSU in the studied wells (after Langford and Blanc-Valleron, 1990).

these thresholds, the majority of samples at wells RS and RR do not reach the equilibrium values. Nevertheless, the studied samples from KR and GS wells have near equilibrium values for these parameters and can be considered thermally mature (Fig. 14).

The $\mathrm{Ts} /(\mathrm{Ts}+\mathrm{Tm})$ ratio should be used with caution because Ts and Tm could be influenced by factors other than maturity such as lithology and organic matter type (Moldowan et al., 1985). Carbonate source rocks have unusually low $\mathrm{Ts} /(\mathrm{Ts}+\mathrm{Tm})$ ratios compared with shales due to catalyzing effects of clay minerals (Peters et al., 2005). The relatively lower maturity of the BSU and the uniform nature of $\mathrm{Ts} /(\mathrm{Ts}+\mathrm{Tm})$ values in the studied samples suggest that the $\mathrm{Ts} / \mathrm{Tm}$ ratio is more influenced by the lithofacies (i.e. carbonate source rock) than the maturity. Moretanes are thermally less stable than hopanes; therefore, the $\mathrm{C}_{30}$ moretane $/ \mathrm{C}_{30}$ hopane ratio decreases with increasing thermal maturity, from approximately 0.8 in immature sediments to less than 0.15 (minimum 0.05) in mature organic matter (Peters et al., 2005; Mackenzie et al., 1980). The RR and RS samples have higher $\mathrm{C}_{30}$ moretane/ $\mathrm{C}_{30}$ hopane ratio (mean= 0.25 ) consistent with the immaturity of these samples. On the other hand, the $\mathrm{C}_{30}$ moretane/ $\mathrm{C}_{30}$ hopane ratio of studied samples from KR and GS wells have values lower than 0.16 , suggesting relatively higher level of maturity.

Maturity interpretations derived from biomarker parameters are also supported by $\mathrm{T}_{\max }$ and vitrinite reflectance values, consistent with a lower level of maturity at wells RR and RS compared to wells KR and GS. These results are well in agreement with previous modeling studies in the studied area, which indicated the Pabdeh Formation has reached the early stage of thermal maturity (e.g. Alizadeh et al., 2012; Bordenave and Hegre, 2010; Opera et al., 2013). The relatively higher maturity of the BSU at wells KR and GS relative to wells RR and RS seems to be at odds with a shallower present-day burial depth at the two former wells (Fig. 3A-D; Table I). This may be a consequence of the recent uplift at KR and GS localities due to the Zagros orogeny. In contrast, the RR and RS localities have experienced gentle folding at the southwestern margin of the Zagros deformation front. This data is also in agreement with the regional geology of the studied area where the structures become progressively younger from NE to SW (Hessami et al., 2001).

\section{Shale oil potential}

Geologically, the fundamental parameters to form an economically recoverable shale oil reserve, are the organic

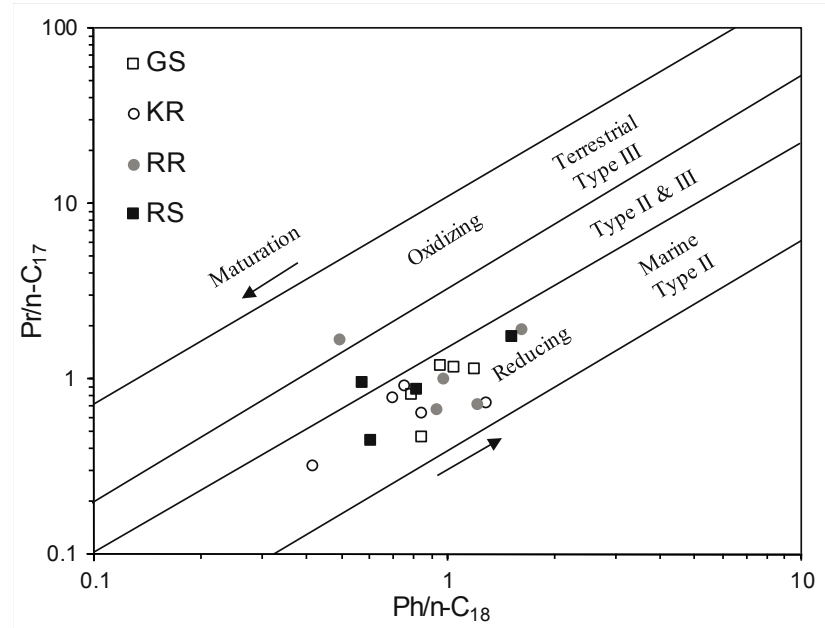

FIGURE 12. Cross-plot of $\mathrm{Pr} / \mathrm{n}-\mathrm{C}_{17}$ versus $\mathrm{Ph} / \mathrm{n}-\mathrm{C}_{18}$ showing Type II kerogen for the Pabdeh BSU, deposited under reducing conditions (after Shanmugam, 1985). 


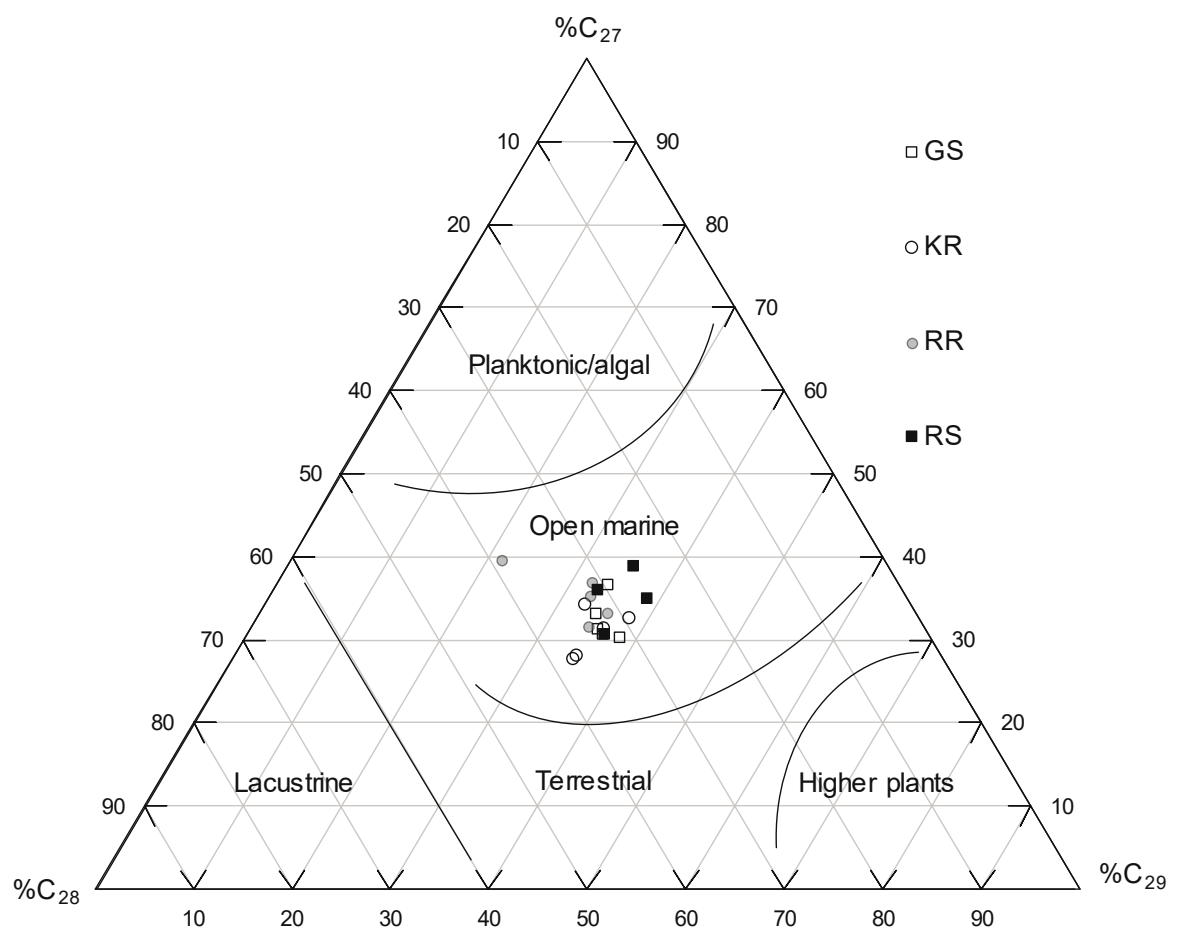

FIGURE 13. Ternary diagram of regular steranes $\left(\mathrm{C}_{27}, \mathrm{C}_{28}\right.$ and $\left.\mathrm{C}_{29}\right)$ showing the open marine-derived organic matter for the $\mathrm{BSU}$ of the Pabdeh Formation.

matter content (TOC $>2 \mathrm{wt} . \%$ ), quality of organic matter (Type I, II or IIS), thermal maturity $(0.6-0.8 \%$ Ro), bed thickness $(>20 \mathrm{~m})$ as well as low percentages of ductile minerals (Misch et al., 2016; Jarvie et al., 2007; Rupprecht et al., 2017).

The relatively thick $(110 \mathrm{~m}$, in average) organic-rich mudstone of the BSU can represent a considerable oil potential by showing high TOC contents (ranging mainly between $1-9 \mathrm{wt} . \%$, with an average of $3.83 \mathrm{wt} . \%$ ) and organic matter of Type II kerogen (HI ranging mainly between 450 $650 \mathrm{mg} \mathrm{HC} / \mathrm{g}$ TOC). Variations in TOC values mimic the vertical trend in natural gamma-ray response in the BSU and the maximum organic richness corresponds with the middle part. This part has a thickness of about $55 \mathrm{~m}$ in the four studied wells and the average organic content amounts to $5.2 \mathrm{wt} . \%$.

A geochemical indicator for evaluation of potentially producible oil from shale plays is provided by the oil crossover effect, which is defined as the Oil Saturation Index $\left(\right.$ OSI $\left.=\mathrm{S}_{1} / \mathrm{TOC} \times 100\right)($ Jarvie, 2012). Samples with OSI higher than about $100 \mathrm{mg} \mathrm{HC/g}$ TOC indicate a considerable potential (Jarvie, 2012). Except for a few samples from wells KR and RS, the OSI values of the BSU are mostly below the crossover point (OSI=100) (Table I; Fig. 15). However, most of KR and GS samples are plotted in an oil show range with OSI values around $70 \mathrm{mg} \mathrm{HC} / \mathrm{g}$ TOC (Fig. 15). Nevertheless, the observed oil contents for studied samples can be influenced to some extents by the evaporative loss of light hydrocarbons during sample storage or preparation (Jarvie, 2012).

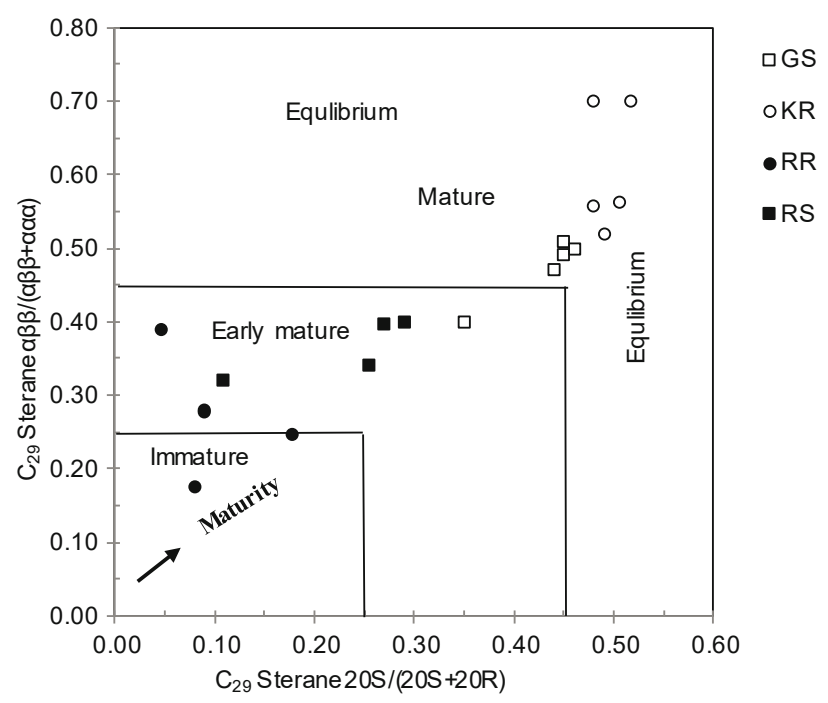

FIGURE 14. $C_{29} 20 S /(20 S+20 R)$ sterane versus $C_{29} \alpha \beta \beta /(\alpha \beta \beta+\alpha \beta \beta)$ sterane indicating thermal maturity for the BSU of the Pabdeh Formation. 


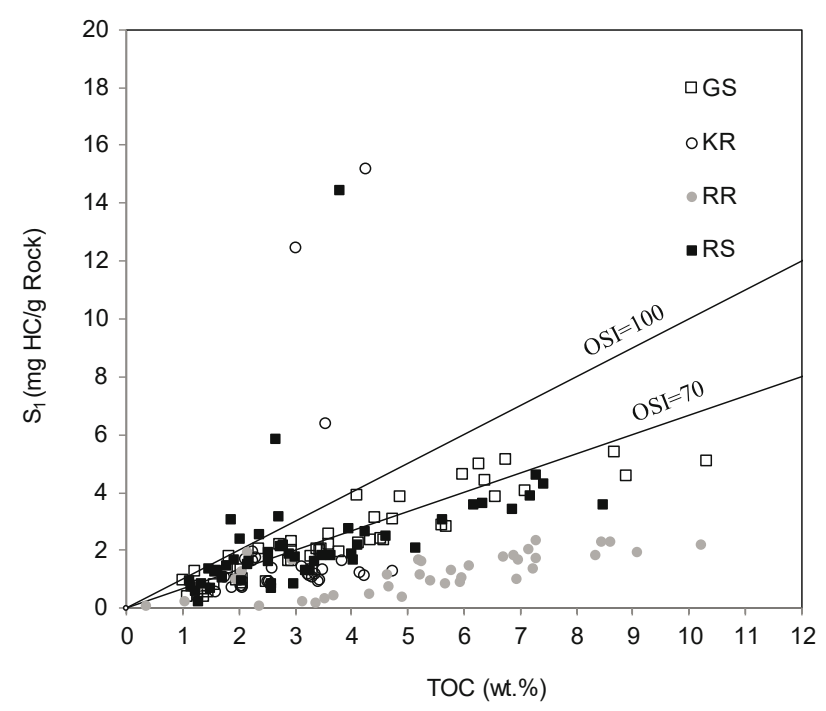

FIGURE 15. TOC vs. $S_{1}$ diagram showing the Oil Saturation Index (OSI) for the Pabdeh BSU in the studied wells.

Resistivity logs were also used to understand the amount of hydrocarbon saturation in the BSU. Variations in pore network and pore fluid are the major causes for changes in resistivity (Lu et al., 2015). Most detrital minerals (quartz, feldspar, and carbonates) are not conductive and form nonconductive rock frameworks. In contrast, presence of clay minerals could reduce the resistivity, and hence decrease the apparent hydrocarbon saturation ( $\mathrm{Lu}$ et al., 2015 and references therein). Nevertheless, mineralogy is not likely to have a major control on resistivity logs in the BSU due to its predominantly carbonaceous composition (Table 1). An increase in the resistivity is also expected when the source rock is enough mature, and a part of its organic matter seem to be transformed into hydrocarbons (Kalani et al., 2015; Kinley et al., 2008; Lu et al., 2015; Passey, 1990). This phenomenon explains the very high resistivity at wells KR and GS compared to wells RR and $\mathrm{RS}$ in the studied area (Fig. 3A-D), which is in agreement with maturity information discussed above. In other words, the increase in resistivity at wells KR and GS compared to two other wells can be the result of higher maturity and hydrocarbon generation in the former well locations.

High silica/carbonate and low clay contents lead to shale brittleness (Bowker, 2007). Brittle minerals not only favor formation of tectonic fractures, but also control the fracability of shales (Gottardi and Mason, 2018). The mineralogical composition of the Pabdeh BSU shows that the prevailing brittle phases are typically calcite $(53 \mathrm{wt} . \%$ in average). The very brittle quartz mineral is about $14 \mathrm{wt} . \%$, in average, whereas the content of ductile clay minerals varies significantly (26wt.\% in average). Generally, results show that the BSU could be brittle except for one sample in well
RR (Table 1). Thus, the high calcite and quartz contents as well as presence of natural fractures in the Pabdeh Formation (Khoshbakht et al., 2009), could suggest that the BSU is a potential candidate for unconventional shale oil exploitation applying hydrofracturing.

\section{CONCLUSIONS}

This study provides new data and interpretations in organic geochemistry, organic petrography and mineralogy of the BSU within the Pabdeh Formation in the southern Dezful Embayment. It also discusses shale oil potential of the BSU in the study area. The BSU is mainly composed of calcite, clay minerals (kaolinite and illite/smectite) and quartz. Minor amounts of ankerite, dolomite and pyrite are also contained.

Most of the studied samples contain TOC between 1 to 9 wt.\%, HI between 400-650mg HC/g TOC, and $\mathrm{S}_{2}$ between 5 to $40 \mathrm{mg} \mathrm{HC} / \mathrm{g}$ rock, indicating that the BSU possess excellent to very good potential for hydrocarbon generation. Organic petrography reveals that organic matter is dominated by AOM and liptinite (alginite), with minor amounts of vitrinite and inertinite, typical of Type II kerogen. Thermal maturity parameters including $\mathrm{T}_{\max }$, vitrinite reflectance and biomarker maturity ratios indicate that the BSU is immature at wells RR and RS attains earlymature to mature stages at wells KR and GS.

Based on bulk geochemical data, acyclic isoprenoids and saturate biomarkers, minimal variation in depositional conditions occurred during deposition of the BSU. The studied shale samples were deposited under anoxic marine conditions that received algal/bacterial organic matter. The presence of oleanane in association with sterane/hopane ratios also suggest that some terrigenous inputs took place during deposition of the BSU.

In summary, considering the organic geochemical and mineralogical information presented in this study we can conclude that the BSU can be a good prospect for shale oil exploitation within the Pabdeh Formation in the southern Dezful Embayment. Therefore, beside its potential as a conventional source rock, some parts of the Pabdeh Formation may constitute unconventional shale oil potential which can influence future exploration/production activities in the Zagros Fold Belt of Iran.

\section{ACKNOWLEDGMENTS}

The authors gratefully acknowledge the Petroleum Geology and Geochemistry Research Center of Shahid Chamran University of Ahvaz (PGGRC) for laboratory facilities. The 
authors are grateful to M. Mirshahani for assistance in organic petrography analysis. Paul Hackley is warmly acknowledged for his contribution to recognition of macerals. The molecular composition was determined at the Department of Applied Geosciences and Geophysics, the Montan Universität Leoben (Austria), which hereby is sincerely acknowledged. The Editor in Chief Miquel Garcés, Associate Editor Ali Ihsan Karayigit and Journal Manager Laura Rincón are thanked for timely handling of the submitted manuscript. Special thanks to anonymous reviewers for their insightful comment and suggestions which significantly improved the paper.

\section{REFERENCES}

Agard, P., Omrani, J., Jolivet, L., Whitechurch, H., Vrielynck, B., Spakman, W., Monié, P., Meyer, B., Wortel, R., 2011. Zagros orogeny: A subduction-dominated process. Geological Magazine, 148, 692-725.

Ala, M.A., Kinghorn, R.R.F, Rahman, M., 1980. Organic geochemistry and source rock characteristics of the Zagros petroleum province, southwest Iran. Journal of Petroleum Geology, 3, 61-89.

Alavi, M., Mahdavi, M.A., 1994. Stratigraphy and structures of the Nahavand region in western Iran, and their implications for the Zagros tectonics. Geological Magazine, 131, 43-47.

Alizadeh, B., Sarafdokht, H., Rajabi, M., Opera, A., Janbaz, M., 2012. Organic geochemistry and petrography of Kazhdumi (Albian-Cenomanian) and Pabdeh (Paleogene) potential source rocks in southern part of the Dezful Embayment, Iran. Organic Geochemistry, 49, 36-46.

Alizadeh, B., Alipour, M., Chehrazi, A., Mirzaie, S., 2017. Chemometric classification and geochemistry of oils in the Iranian sector of the southern Persian Gulf Basin. Organic Geochemistry, 111, 67-81.

Alizadeh, B., Maroufi, K., Fajrak, M., 2018a. Hydrocarbon reserves of Gachsaran oilfield, SW Iran: Geochemical characteristics and origin. Marine and Petroleum Geology, 92, 308-318.

Alizadeh, B., Maroufi, K., Heidarifard, M.H., 2018b. Estimating source rock parameters using wireline data: An example from Dezful Embayment, South West of Iran. Journal of Petroleum Science and Engineering, 167, 857-868.

Alizadeh, B., Seyedali, S.R., Sarafdokht, H., 2019. Effect of bitumen and migrated oil on hydrocarbon generation kinetic parameters derived from Rock-Eval pyrolysis. Petroleum Science and Technology, 37, 2114-2121.

Asadi Mehmandosti, E., Adabi, M.H., Bowden, S.A., Alizadeh, B., 2015. Geochemical investigation, oil-oil and oil-source rock correlation in the Dezful Embayment, Marun oilfield, Zagros, Iran. Marine and Petroleum Geology, 68, 648-663.

Bahroudi, A., Talbot, C.J., 2003. The configuration of the basement beneath the Zagros Basin. Journal of Petroleum Geology, 26, 257-282.

Baniasad, A., Rabbani, A., Sachse, V.F, Littke, R., Moallemi, S.A., Soleimany, B., 2016. 2D basin modeling study of the
Binak Trough, northwestern Persian Gulf, Iran. Marine and Petroleum Geology, 77, 882-897.

Baniasad, A., Sachse, V., Littke, R., Soleimany, B., 2019. Burial, temperature and maturation history of cretaceous source rocks in the NW Persian Gulf, offshore SW Iran: 3D basin modelling. Journal of Petroleum Geology, 42, 125-144.

Bergmann, J., Friedel, P., Kleeberg, R., 1998. BGMN-a new fundamental parameters based Rietveld program for laboratory X-ray sources, it's use in quantitative analysis and structure investigations. CPD Newsletter, Commission of Powder Diffraction. International Union of Crystallography, 20, 5-8.

Bergmann, J., Kleeberg, R., Ufer, K., Friedel, P., 2014. Official Websiteofthe BGMN Software. Last accessed: March 2014. Website: http://www.bgmn.de

Bjørlykke, K., 2010. Compaction of Sedimentary Rocks Including Shales. In: Bjørlykke, K. (ed.). Sandstones and Carbonates Petroleum Geoscience. Springer Berlin Heidelberg, 329-337.

Bordenave, M.L., Burwood, R., 1990. Source rock distribution and maturation in the Zagros Orogenic Belt: Provenance of the Asmari and Bangestan Reservoir oil accumulations. Organic Geochemistry, 16, 369-387.

Bordenave, M.L., Hegre, J.A., 2005. The influence of tectonics on the entrapment of oil in the Dezful Embayment, Zagros Foldbelt, Iran. Journal of Petroleum Geology, 28, 339-368.

Bordenave, M.L., Hegre, J.A., 2010. Current distribution of oil and gas fields in the Zagros Fold Belt of Iran and contiguous offshore as the result of the petroleum systems. London, Geological Society, 330 (Special Publications), 291-353.

Bordenave, M.L., 2014. Petroleum Systems and Distribution of the Oil and Gas fields in the Iranian Part of the Tethyan Region. American Association of Petroleum Geologists (AAPG), 106 (Memoir), 505-540.

Bowker, K.A., 2007. Barnett Shale gas production, Fort Worth Basin: Issues and discussion. American Association of Petroleum Geologists (AAPG), 91 (Bulletin), 523-533.

Curiale, J.A., Curtis, J.B., 2016. Organic geochemical applications to the exploration for source-rock reservoirs - A review. Journal of Unconventional Oil Gas Resource, 13, 1-31.

Dembicki, H., 2009. Three common source rock evaluation errors made by geologists during prospect or play appraisals. American Association of Petroleum Geologists (AAPG), 93 (Bulletin), 341-356.

Dow, W.G., 1977. Kerogen studies and geological interpretations. Journal of Geochemical Exploration, 7, 79-99.

Fang, H., Jianyu, C., Yongchuan, S., Yaozong, L., 1993. Application of organic facies studies to sedimentary basin analysis: a case study from the Yitong Graben, China. Organic Geochemistry, 20, 27-42.

Ghassal, B.I., Littke, R., Sachse, V., Sindern, S., Schwarzbauer, J., 2016. Depositional environment and source rock potential of cenomanian and turonian sedimentary rocks of the tarfaya basin, Southwest Morocco. Geologica Acta, 14(4), 419-441.

Gottardi, R., Mason, S.L., 2018. Characterization of the natural fracture system of the eagle ford formation (Val Verde County, 
Texas). American Association of Petroleum Geologists (AAPG), 102 (Bulletin), 1963-1984.

Gross, D., Sachsenhofer, R.F, Bechtel, A., Pytlak, L., Rupprecht, B., Wegerer, E., 2015. Organic geochemistry of Mississippian shales (Bowland Shale Formation) in central Britain: Implications for depositional environment, source rock and gas shale potential. Marine and Petroleum Geology, 59, 1-21.

Habibi, T., Nielsen, J.K., Ponedelnik, A.A., Ruban, D.A., 2017. Palaeogeographical peculiarities of the Pabdeh Formation (Paleogene) in Iran: New evidence of global diversitydetermined geological heritage. Journal of African Earth Sciences, 135, 24-33.

Hackley, P.C., Cardott, B.J., 2016. Application of organic petrography in North American shale petroleum systems: A review. International Journal of Coal Geology, 163, 8-51.

Hatampour, A., 2014. Using rock eval pyrolysis for studying the hydrocarbon potential of the Pabdeh formation in Ziluee oilfield, South West of Iran. Petroleum Science and Technology, 32, 1586-1597.

Hessami, K., Koyi, H.A., Talbot, C.J., Tabasi, H., Shabanian, E., 2001. Progressive unconformities within an evolving foreland fold-thrust belt, Zagros Mountains. Journal of the Geological Society, 158, 969-981.

Homke, S., Vergés, J., Garcés, M., Emami, H., Karpuz, R., 2004. Magnetostratigraphy of Miocene-Pliocene Zagros foreland deposits in the front of the Push-e Kush Arc (Lurestan Province, Iran). Earth and Planetary Science Letters, 225, 397-410.

Huang, W.Y., Meinschein, W.G., 1979. Sterols as ecological indicators. Geochimica et Cosmochimica Acta, 43, 739-745.

Hunt, J.M., 1996. Petroleum Geochemistry and Geology. New York, W.H. Freeman, 2nd edition, 734pp.

Hutton, A.C., Cook, A.C., 1980. Influence of alginite on the reflectance of vitrinite from Joadja, NSW, and some other coals and oil shales containing alginite. Fuel, 59, 711-714.

James, G.A., Wynd, J.G., 1965. Stratigraphic Nomenclature of Iranian Oil Consortium Agreement Area. American Association of Petroleum Geologists (AAPG), 49 (Bulletin), 2182-2245.

Jarvie, D.M., Claxton, B.L., Henk, F., Breyer, J.T., 2001. Oil and shale gas from the Barnett Shale. American Association of Petroleum Geologists (AAPG) Annual Meeting Program, 10, A100.

Jarvie, D.M., Hill, R.J., Ruble, T.E., Pollastro, R.M., 2007. Unconventional shale-gas systems: The Mississippian Barnett Shale of north-central Texas as one model for thermogenic shale-gas assessment. American Association of Petroleum Geologists (AAPG), 91 (Bulletin), 475-499.

Jarvie, D.M., 2012. Shale Resource Systems for Oil and Gas: Part 2-Shale-oil Resource Systems. In: Breyer, J.A. (ed.). Shale Reservoirs-Giant Resources for the 21st Century. American Association of Petroleum Geologists (AAPG), 97 (Memoir), 89-119.

Jarvie, D.M., 2014. Components and processes affecting producibility and commerciality of shale resource systems. Geologica Acta, 12(4), 307-325.
Kalani, M., Jahren, J., Mondol, N.H., Faleide, J.I., 2015. Petrophysical implications of source rock microfracturing. International Journal of Coal Geology, 143, 43-67.

Karimi, A.R., Rabbani, A.R., Kamali, M.R., 2016a. A bulk kinetic, burial history and thermal modeling study of the Albian Kazhdumi and the Eocene-Oligocene Pabdeh formations in the Ahvaz anticline, Dezful Embayment, Iran. Journal of Petroleum Science and Engineering, 146, 61-70.

Karimi, A.R., Rabbani, A.R., Kamali, M.R., Heidarifard, M.H., 2016b. Geochemical evaluation and thermal modeling of the Eocene-Oligocene Pabdeh and Middle Cretaceous Gurpi Formations in the northern part of the Dezful Embayment. Arabian Journal of Geosciences, 9(423), 1-16.

Khoshbakht, F., Memarian, H., Mohammadnia, M., 2009. Comparison of Asmari, Pabdeh and Gurpi formation's fractures, derived from image log. Journal of Petroleum Science and Engineering, 67, 65-74.

Kinley, T.J., Cook, L.W., Breyer, J.A., Jarvie, D.M., Busbey, A.B., 2008. Hydrocarbon potential of the Barnett Shale (Mississippian), Delaware Basin, west Texas and southeastern New Mexico. American Association of Petroleum Geologists (AAPG), 92 (Bulletin), 967-991.

Langford, FF, Blanc-Valleron, M.M., 1990. Interpreting RockEval pyrolysis data using graphs of pyrolizable hydrocarbons vs. total organic carbon. American Association of Petroleum Geologists (AAPG), 74 (Bulletin), 799-804.

Li, L., Yao, G.Q., Cai, M.J., Liu, Y.H., 2018. Organic petrology and geochemistry of mudstones from the lower Shahejie Formation in the Tanggu area of eastern China: Evidence for the presence of an ancient saline lake. Geologica Acta, 16(1), 45-64.

Lu, J., Ruppel, S.C., Rowe, H.D., 2015. Organic matter pores and oil generation in the Tuscaloosa marine shale. American Association of Petroleum Geologists (AAPG), 99 (Bulletin), 333-357.

Mackenzie, A.S., Patience, R.L., Maxwell, J.R., Vandenbroucke, M., Durand, B., 1980. Molecular parameters of maturation in the Toarcian shales, Paris Basin, France-I. Changes in the configurations of acyclic isoprenoid alkanes, steranes and triterpanes. Geochimica et Cosmochimica Acta, 44, 17091721.

Magoon, L.B., Dow, W.G., 1994. The petroleum system-from source to trap. American Association of Petroleum Geologists (AAPG), 60 (Memoir), 25-49.

Mashhadi, Z.S., Rabbani, A.R., Kamali, M.R., 2015. Geochemical characteristics and hydrocarbon generation modeling of the Kazhdumi (Early Cretaceous), Gurpi (Late Cretaceous) and Pabdeh (Paleogene) formations, Iranian sector of the Persian Gulf. Marine and Petroleum Geology, 66, 978-997.

Mello, M.R., Telnaes, N., Gaglianone, P.C., 1988. Organic geochemical characterization of depositional paleoenvironments in Brazilian marginal basins. Organic Geochemistry, 13, 31-46.

Misch, D., Gross, D., Mahlstedt, N., Makogon, V., Sachsenhofer, R.F., 2016. Shale gas/shale oil potential of Upper Visean 
Black Shales in the Dniepr-Donets Basin (Ukraine). Marine and Petroleum Geology, 75, 203-219.

Moldowan, J.M., Seifert, W.K., 1985. Relationship between petroleum composition and depositional environment of petroleum source rocks. American Association of Petroleum Geologists (AAPG), 69 (Bulletin), 1255-1268.

Moldowan, J.M., Sundararaman, P., Schoell, M., 1986. Sensitivity of biomarker properties to depositional environment and/ or source input in the Lower Toarcian of SW-Germany. In: Leythaeuser, D., Rullkotter, H. (eds.). Advances in Organic Geochemistry. Organic Geochemistry, 10, 915-926.

Mouthereau, F., Lacombe, O., Vergés, J., 2012. Building the Zagros collisional orogen: Timing, strain distribution and the dynamics of Arabia/Eurasia plate convergence. Tectonophysics, 532-535, 27-60.

Nadeau, P.H., 2011. Earth's energy "Golden Zone": a synthesis from mineralogical research. Clay Minerals, 46, 1-24.

Opera, A., Alizadeh, B., Sarafdokht, H., Janbaz, M., Fouladvand, R., Heidarifard, M.H., 2013. Burial history reconstruction and thermal maturity modeling for the Middle Cretaceous-Early Miocene Petroleum System, southern Dezful Embayment, SW Iran. International Journal of Coal Geology, 120, 1-14.

Passey, Q.R., 1990. A Practical Guide for Organic Richness from Porosity and Resistivity. American Association of Petroleum Geologists (AAPG), 12 (Bulletin), 1777-1794.

Permanyer, A., Jorge, R., Baudino, R., Gibert, L., 2016. Organicrich shales from internal betic basins (SE Spain): Potential source rocks analogs for the pre-messinian salt play in the western mediterranean. Geologica Acta, 14(4), 443-460.

Peters, K.E., Casa, M.R., 1994. Applied source rock geochemistry. In: Magoon, L.B., Dow, W.G. (eds.). The petroleum systemfrom source to trap. American Association of Petroleum Geologists (AAPG), 60 (Memoir), 93-120.

Peters, K.E., Walters, C.C., Moldowan, J.M., 2005. The Biomarker Guide Volume 2: Biomarkers and Isotopes in Petroleum Systems and Earth History. Cambridge University Press, 680pp.

Poppe, L.J., Paskevich, V.F, Hathaway, J.C., Blackwood, D.S., 2001. A laboratory manual for X-ray powder diffraction. US Geological Survey Open-File Report, 1, 88pp.

Rabbani, A.R., Kotarba, M.J., Baniasad, A.R., Hosseiny, E., Wieclaw, D., 2014. Geochemical characteristics and genetic types of the crude oils from the Iranian sector of the Persian Gulf. Organic Geochemistry, 70, 29-43.

Rupprecht, B.J., Sachsenhofer, R.F., Gawlick, H.J., Kallanxhi, M.E., Kucher, F, 2017. Jurassic source rocks in the Vienna Basin (Austria): Assessment of conventional and unconventional petroleum potential. Marine and Petroleum Geology, 86, 1327-1356.
Seifert, W.K., Moldowan, J.M., 1977. Applications of steranes, terpanes and monoaromatics to the maturation, migration and source of crude oils. Geochimica et Cosmochimica Acta, 42, 77-95.

Seifert, W.K., Moldowan, J.M., 1980. The effect of thermal stress on source-rock quality as measured. Physics and Chemistry of the Earth, 12, 229-237.

Seifert, W.K., Moldowan, J.M., 1986. Use of biological markers in petroleum exploration. Methods in Geochemistry and Geophysics, 24, 261-290.

Sepehr, M., Cosgrove, J.W., 2004. Structural framework of the Zagros Fold-Thrust Belt, Iran. Marine and Petroleum Geology, 21, 829-843.

Shanmugam, G., 1985. Significance of coniferous rain forests and related organic matter in generating commercial quantities of oil, Gippsland Basin, Australia. American Association of Petroleum Geologists (AAPG), 69 (Bulletin), 1241-1254.

Sherkati, S., Letouzey, J., De Lamotte, D.F., 2006. Central Zagros fold-thrust belt (Iran): New insights from seismic data, field observation, and sandbox modeling. Tectonics, 25, 1-27.

Soleimani, B., Zamani, F, 2015. Preliminary petroleum source rock evaluation of the Asmari--Pabdeh reservoirs, Karanj and Parsi oilfields, Zagros, Iran. Journal of Petroleum Science and Engineering, 134, 97-104.

Song, Y., Liu, Z., Sun, P., Meng, Q., Liu, R., 2017. A comparative geochemistry study of several oil shale-bearing intervals in the Paleogene Huadian Formation, Huadian Basin, Northeast China. Journal of Earth Science, 28, 645-655.

Taylor, G.H., Teichmüller, M., Davis, A., Diessel, C.FK., Littke, R., Robert, P., 1998. Organic petrology. Stuttgart (Borntraeger), Schweizerbart Science Publishers, 704pp.

Uffmann, A.K., Littke, R., Rippen, D., 2012. Mineralogy and geochemistry of Mississippian and Lower Pennsylvanian Black Shales at the Northern Margin of the Variscan Mountain Belt (Germany and Belgium). International Journal of Coal Geology, 103, 92-108.

Waples, D.W., Machihara, T., 1992. Biomarkers for Geologists: A Practical Guide to the Application of Steranes and Triterpanes in Petroleum Geology. Tulsa, American Association of Petroleum Geologists Methods in Exploration, 9, 91pp.

Tissot, B., Welte, D.H., 1984. Petroleum Formation and Occurrence. New York, Springer-Verlag, 699pp.

Zhao, X., Li, Q., Jiang, Z., Zhang, R., Li, H., 2014. Organic geochemistry and reservoir characterization of the organic matter-rich calcilutite in the Shulu Sag, Bohai Bay Basin, North China. Marine and Petroleum Geology, 51, 239-255.

\footnotetext{
Manuscript received November 2019;

revision accepted June 2020;

published Online October 2020.
} 


\section{APPENDIX I}

TABLE I. Results of Rock-Eval pyrolysis and measured vitrinite reflectance data

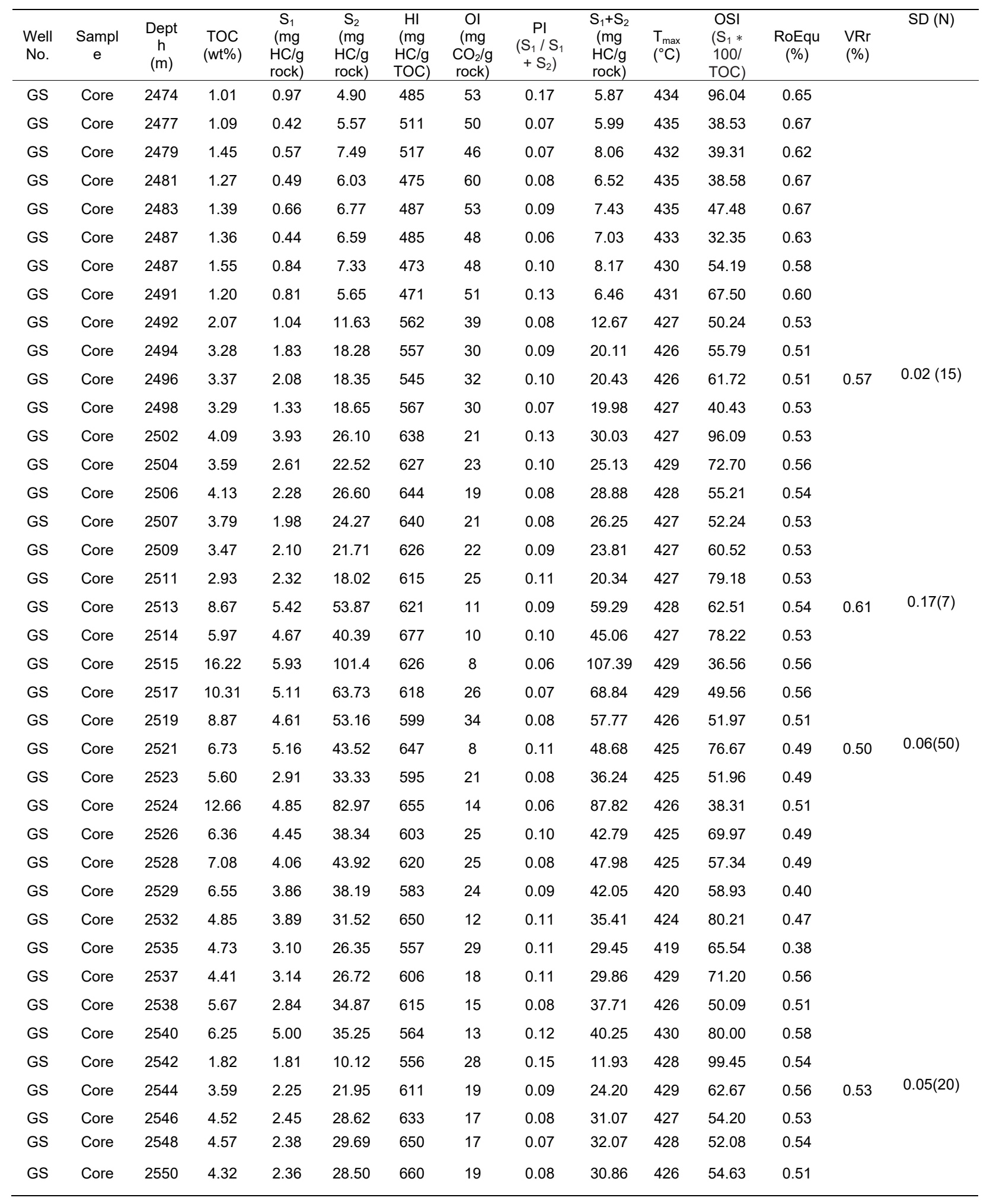


TABLE I. Continued

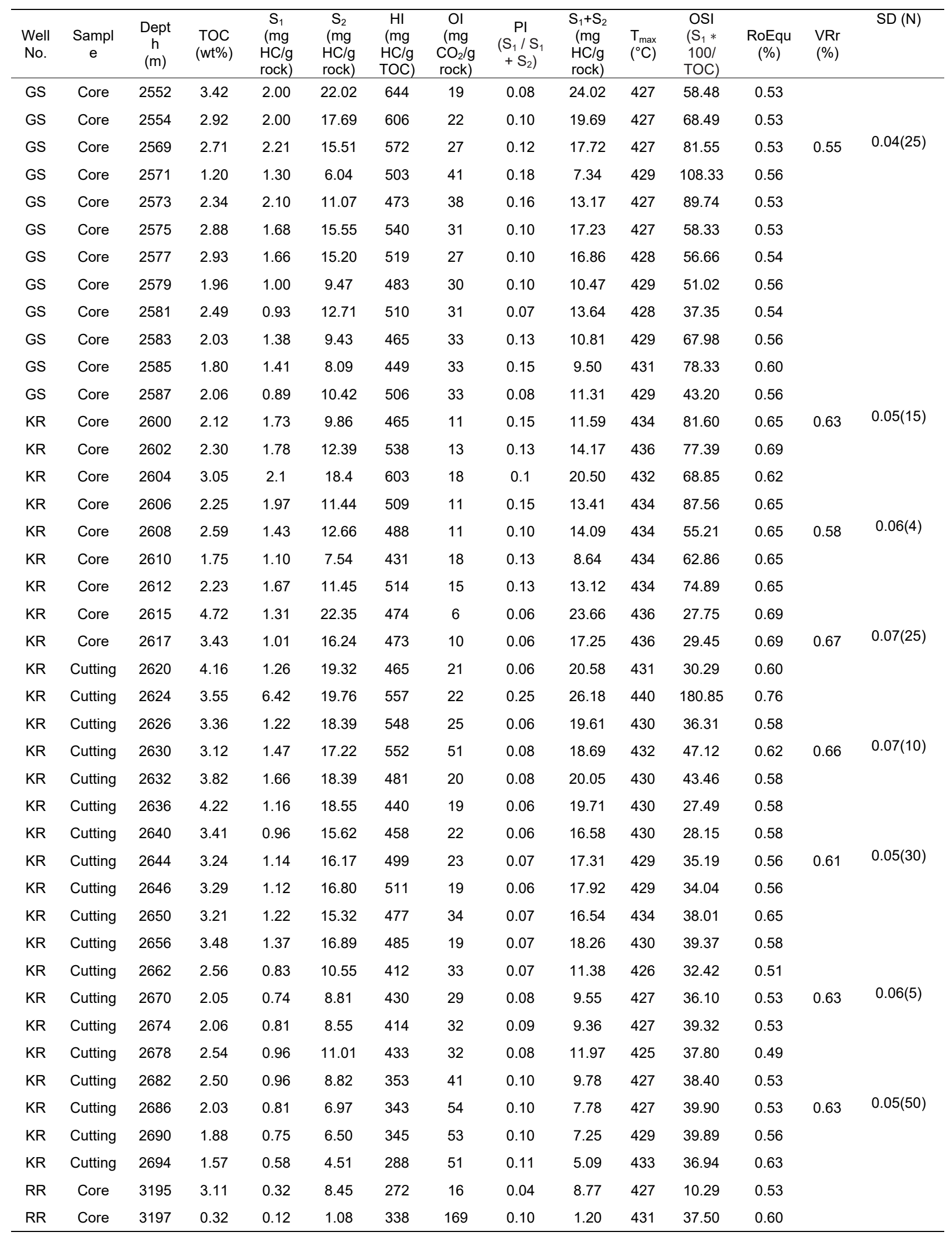


TABLE I. Continued

\begin{tabular}{|c|c|c|c|c|c|c|c|c|c|c|c|c|c|c|}
\hline $\begin{array}{l}\text { Well } \\
\text { No. }\end{array}$ & $\begin{array}{c}\text { Sampl } \\
\mathrm{e}\end{array}$ & $\begin{array}{c}\text { Dept } \\
\text { h } \\
(\mathrm{m})\end{array}$ & $\begin{array}{l}\text { TOC } \\
\text { (wt\%) }\end{array}$ & $\begin{array}{c}\mathrm{S}_{1} \\
(\mathrm{mg} \\
\mathrm{HC} / \mathrm{g} \\
\mathrm{rock})\end{array}$ & $\begin{array}{c}\mathrm{S}_{2} \\
(\mathrm{mg} \\
\mathrm{HC} / \mathrm{g} \\
\text { rock) }\end{array}$ & $\begin{array}{c}\mathrm{HI} \\
(\mathrm{mg} \\
\mathrm{HC} / \mathrm{g} \\
\mathrm{TOC}) \\
\end{array}$ & $\begin{array}{c}\mathrm{OI} \\
(\mathrm{mg} \\
\mathrm{CO}_{2} / \mathrm{g} \\
\text { rock) }\end{array}$ & $\begin{array}{c}\mathrm{Pl} \\
\left(\mathrm{S}_{1} / \mathrm{S}_{1}\right. \\
\left.+\mathrm{S}_{2}\right)\end{array}$ & $\begin{array}{c}\mathrm{S}_{1}+\mathrm{S}_{2} \\
(\mathrm{mg} \\
\mathrm{HC} / \mathrm{g} \\
\text { rock) }\end{array}$ & $\begin{array}{l}\mathrm{T}_{\max } \\
\left({ }^{\circ} \mathrm{C}\right)\end{array}$ & $\begin{array}{c}\text { OSI } \\
\left(\mathrm{S}_{1} *\right. \\
100 / \\
\text { TOC) } \\
\end{array}$ & $\begin{array}{c}\text { RoEqu } \\
(\%)\end{array}$ & $\begin{array}{l}\mathrm{VRr} \\
(\%)\end{array}$ & $\mathrm{SD}(\mathrm{N})$ \\
\hline $\mathrm{RR}$ & Core & 3201 & 3.33 & 0.25 & 5.33 & 160 & 25 & 0.05 & 5.58 & 432 & 7.51 & 0.62 & & \\
\hline $\mathrm{RR}$ & Core & 3204 & 3.49 & 0.39 & 9.63 & 276 & 17 & 0.04 & 10.02 & 425 & 11.17 & 0.49 & 0.41 & $0.03(26)$ \\
\hline RR & Core & 3206 & 3.67 & 0.48 & 14.84 & 404 & 15 & 0.03 & 15.32 & 425 & 13.08 & 0.49 & & \\
\hline $\mathrm{RR}$ & Core & 3208 & 4.87 & 0.45 & 11.60 & 238 & 12 & 0.04 & 12.05 & 424 & 9.24 & 0.47 & & \\
\hline $\mathrm{RR}$ & Core & 3210 & 1.02 & 0.28 & 4.71 & 462 & 31 & 0.06 & 4.99 & 432 & 27.45 & 0.62 & 0.42 & $0.06(48)$ \\
\hline $\mathrm{RR}$ & Core & 3213 & 2.33 & 0.15 & 3.23 & 139 & 21 & 0.04 & 3.38 & 430 & 6.44 & 0.58 & 0.41 & $0.12(23)$ \\
\hline $\mathrm{RR}$ & Core & 3215 & 5.63 & 0.91 & 23.38 & 415 & 11 & 0.04 & 24.29 & 421 & 16.16 & 0.42 & & \\
\hline $\mathrm{RR}$ & Core & 3218 & 4.28 & 0.58 & 10.28 & 240 & 15 & 0.05 & 10.86 & 418 & 13.55 & 0.36 & & \\
\hline $\mathrm{RR}$ & Core & 3220 & 5.39 & 1.04 & 19.51 & 362 & 13 & 0.05 & 20.55 & 417 & 19.29 & 0.35 & 0.54 & $0.08(26)$ \\
\hline $\mathrm{RR}$ & Core & 3222 & 6.68 & 1.85 & 34.21 & 512 & 11 & 0.05 & 36.06 & 420 & 27.69 & 0.40 & & \\
\hline $\mathrm{RR}$ & Core & 3224 & 5.75 & 1.38 & 26.82 & 466 & 12 & 0.05 & 28.20 & 419 & 24.00 & 0.38 & & \\
\hline $\mathrm{RR}$ & Core & 3226 & 4.60 & 1.23 & 21.61 & 470 & 12 & 0.05 & 22.84 & 417 & 26.74 & 0.35 & & \\
\hline $\mathrm{RR}$ & Core & 3230 & 6.90 & 1.09 & 25.09 & 364 & 6 & 0.04 & 26.18 & 417 & 15.80 & 0.35 & 0.46 & $0.08(30)$ \\
\hline $\mathrm{RR}$ & Core & 3234 & 5.90 & 0.98 & 22.25 & 377 & 14 & 0.04 & 23.23 & 418 & 16.61 & 0.36 & & \\
\hline $\mathrm{RR}$ & Core & 3237 & 4.64 & 0.81 & 21.63 & 466 & 13 & 0.04 & 22.44 & 420 & 17.46 & 0.40 & & \\
\hline $\mathrm{RR}$ & Core & 3240 & 7.19 & 1.43 & 29.64 & 412 & 9 & 0.05 & 31.07 & 416 & 19.89 & 0.33 & & \\
\hline $\mathrm{RR}$ & Core & 3242 & 6.94 & 1.72 & 33.91 & 489 & 9 & 0.05 & 35.63 & 419 & 24.78 & 0.38 & 0.43 & $0.12(32)$ \\
\hline $\mathrm{RR}$ & Core & 3244 & 8.43 & 2.38 & 46.83 & 556 & 9 & 0.05 & 49.21 & 417 & 28.23 & 0.35 & & \\
\hline $\mathrm{RR}$ & Core & 3246 & 10.19 & 2.27 & 39.84 & 391 & 19 & 0.05 & 42.11 & 416 & 22.28 & 0.33 & & \\
\hline RR & Core & 3248 & 7.26 & 2.43 & 44.51 & 613 & 9 & 0.05 & 46.94 & 420 & 33.47 & 0.40 & 0.44 & $0.11(95)$ \\
\hline $\mathrm{RR}$ & Core & 3251 & 8.57 & 2.34 & 44.29 & 517 & 9 & 0.05 & 46.63 & 422 & 27.30 & 0.44 & & \\
\hline $\mathrm{RR}$ & Core & 3254 & 6.86 & 1.90 & 31.83 & 464 & 6 & 0.06 & 33.73 & 420 & 27.70 & 0.40 & & \\
\hline $\mathrm{RR}$ & Core & 3256 & 9.04 & 2.00 & 41.45 & 459 & 10 & 0.05 & 43.45 & 419 & 22.12 & 0.38 & & \\
\hline $\mathrm{RR}$ & Core & 3260 & 7.25 & 1.78 & 36.96 & 510 & 20 & 0.05 & 38.74 & 415 & 24.55 & 0.31 & & \\
\hline $\mathrm{RR}$ & Core & 3262 & 8.30 & 1.87 & 38.09 & 459 & 10 & 0.05 & 39.96 & 418 & 22.53 & 0.36 & 0.52 & $0.1(35)$ \\
\hline $\mathrm{RR}$ & Core & 3264 & 7.11 & 2.11 & 33.19 & 467 & 12 & 0.06 & 35.30 & 416 & 29.68 & 0.33 & & \\
\hline $\mathrm{RR}$ & Core & 3268 & 6.07 & 1.51 & 35.90 & 591 & 8 & 0.04 & 37.41 & 421 & 24.88 & 0.42 & & \\
\hline $\mathrm{RR}$ & Core & 3271 & 5.17 & 1.75 & 29.53 & 571 & 8 & 0.06 & 31.28 & 422 & 33.85 & 0.44 & & \\
\hline $\mathrm{RR}$ & Core & 3275 & 5.93 & 1.10 & 18.35 & 309 & 12 & 0.06 & 19.45 & 423 & 18.55 & 0.45 & 0.50 & $0.05(30)$ \\
\hline $\mathrm{RR}$ & Core & 3278 & 5.19 & 1.24 & 17.67 & 340 & 14 & 0.07 & 18.91 & 423 & 23.89 & 0.45 & & \\
\hline $\mathrm{RR}$ & Core & 3281 & 1.92 & 1.08 & 12.77 & 665 & 27 & 0.08 & 13.85 & 424 & 56.25 & 0.47 & & \\
\hline $\mathrm{RR}$ & Core & 3283 & 2.02 & 1.32 & 14.83 & 734 & 30 & 0.08 & 16.15 & 424 & 65.35 & 0.47 & 0.34 & $0.04(50)$ \\
\hline $\mathrm{RR}$ & Cutting & 3292 & 2.13 & 2.00 & 16.29 & 765 & 72 & 0.11 & 0.11 & 422 & 93.90 & 0.44 & & \\
\hline $\mathrm{RR}$ & Cutting & 3300 & 2.93 & 1.73 & 11.36 & 388 & 88 & 0.13 & 13.09 & 408 & 59.04 & 0.18 & & \\
\hline $\mathrm{RR}$ & Cutting & 3310 & 5.21 & 1.69 & 11.88 & 228 & 51 & 0.12 & 13.57 & 426 & 32.44 & 0.51 & 0.37 & $0.08(48)$ \\
\hline $\mathrm{RR}$ & Cutting & 3318 & 1.24 & 0.80 & 3.63 & 293 & 169 & 0.18 & 0.18 & 430 & 64.52 & 0.63 & & \\
\hline RS & Core & 2277 & 3.18 & 1.34 & 19.95 & 627 & 37 & 0.06 & 21.29 & 421 & 42.14 & 0.42 & & \\
\hline RS & Core & 2279 & 3.61 & 1.88 & 20.93 & 580 & 32 & 0.08 & 22.81 & 418 & 52.08 & 0.36 & 0.54 & $0.08(28)$ \\
\hline RS & Core & 2280 & 2.69 & 3.22 & 16.05 & 597 & 42 & 0.17 & 19.27 & 422 & 119.70 & 0.44 & & \\
\hline RS & Core & 2283 & 4.01 & 1.70 & 25.11 & 626 & 30 & 0.06 & 26.81 & 420 & 42.39 & 0.40 & 0.43 & $0.06(30)$ \\
\hline RS & Core & 2284 & 3.45 & 1.86 & 21.15 & 613 & 30 & 0.08 & 23.01 & 421 & 53.91 & 0.42 & & \\
\hline RS & Core & 2304 & 6.17 & 3.62 & 37.43 & 607 & 33 & 0.09 & 41.05 & 417 & 58.67 & 0.35 & & \\
\hline RS & Core & 2305 & 7.40 & 4.35 & 46.93 & 634 & 27 & 0.08 & 51.28 & 417 & 58.78 & 0.35 & & \\
\hline RS & Core & 2306 & 6.85 & 3.49 & 42.48 & 620 & 29 & 0.08 & 45.97 & 417 & 50.95 & 0.35 & & \\
\hline
\end{tabular}


TABLE I. Continued

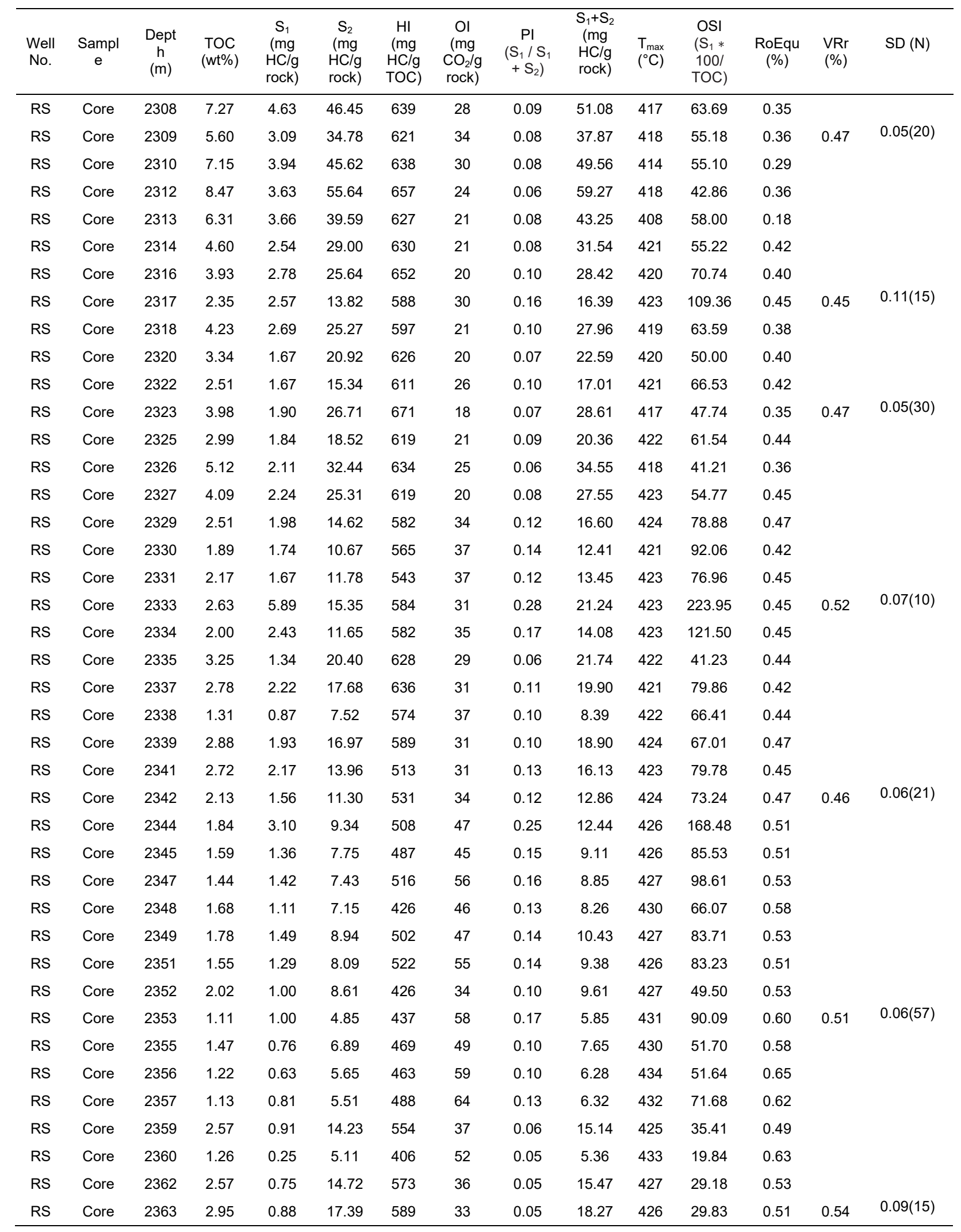

TOC= total organic carbon; $\mathrm{S}_{1}=$ volatile hydrocarbon content; $\mathrm{S}_{2}=$ remaining hydrocarbon generative potential; $\mathrm{S}_{3}=$ carbon dioxide content; $\mathrm{HI}=$ hydrogen index; $\mathrm{Ol}=$ oxygen index; $\mathrm{Pl}=$ production index; $\mathrm{S}_{1}+\mathrm{S}_{2}=$ generation potential; $\mathrm{T}_{\max }=$ the temperature of the maximum generation rate of kerogen cracking; $\mathrm{OSI}=$ oil saturation index; Requ= equivalent vitrinite reflectance; $\mathrm{VRr}=$ random vitrinite reflectance; $\mathrm{SD}=\mathrm{standard}$ deviation of vitrinite reflectance measurements; $N=$ Number of measurements. 